\title{
Geochemistry of Melt Inclusions from the Fondo Riccio and Minopoli 1 Eruptions at Campi Flegrei (Italy)
}

\author{
Claudia Cannatelli \\ Thesis submitted to the faculty of the \\ Virginia Polytechnic Institute and State University \\ in partial fulfillment of the requirements for the degree of \\ MASTER OF SCIENCE \\ in \\ Geosciences \\ R.J. Bodnar, Chairman \\ R.J. Tracy \\ B. De Vivo
}

May 18, 2006

Blacksburg, Virginia

Keywords: Volcanic risk, Campi Flegrei, melt inclusions, volatiles. 


\title{
Geochemistry of Melt Inclusions from the Fondo Riccio and Minopoli 1 Eruptions at Campi Flegrei (Italy)
}

\author{
Claudia Cannatelli
}

\begin{abstract}
Campi Flegrei is a large volcanic complex located west of the city of Naples, Italy. The area has been the site of volcanic activity for more than $60 \mathrm{ka}$ and represents a potential volcanic hazard owing to the large local population. In this study, the geochemistry of the magma associated with two different eruptions at Campi Flegrei has been characterized, with the aim to identify geochemical trends that may help to predict the style and nature of future eruptions. Two eruptions of different age and eruptive style have been selected for study, Fondo Riccio (9.5 ka) and Minopoli 1 (11.1 ka). A scoria (CF-FR-C1) and a bomb (CF-FR-C2) were collected from the Fondo Riccio eruption, and two scoria samples were collected from Minopoli 1 (CF-Mi1-C1 and C2) eruption.

The pre-eruptive volatile content of magma plays an important role in the style of eruption and can be assessed from studies of melt inclusions (MI) contained in phenocrysts. Major and trace elements in Fondo Riccio MI show a wider variation compared to those in Minopoli $1 \mathrm{MI}$ suggesting that the Fondo Riccio magma residence time was longer compared to the Minopoli 1 magma. Analyses of volatile contents in MI suggest that Fondo Riccio magma may have been more water-rich than Minopoli 1 magma, consistent with the more explosive character of this eruption compared to Minopoli 1. Trace element data suggest a combination of arc volcanic and upper continental crust magma as the source for the Fondo Riccio and Minopoli 1 eruptions.
\end{abstract}




\section{Acknowledgments}

I would like to express my sincere gratitude to my committee members, Dr. Bob Bodnar, Dr. Benedetto De Vivo and Dr. Bob Tracy for their guidance and encouragement. Without their assistance and support, this work would not have been possible. I thank my advisor Bob Bodnar for his outstanding teaching, patience and invaluable advice. I will be always grateful for his contribution to my development as a scientist and critical thinker. I would like to thank Benedetto De Vivo for accepting me as his student at the University of Naples, Italy (even if I wasn’t a geologist!) and for giving me the chance to come to the USA and work on such an interesting project! Thanks to Bob Tracy to introduce me to the wonderful (and mysterious) world of the EMPA and Dr. Annamaria Lima for her patience in helping me deal with geochemical data.

There are not enough words to explain my gratitude for Dr. Luca Fedele. He is first of all a good friend and an extraordinary colleague, and he supported me with invaluable suggestions and advice. My experimental work would not have been possible without the assistance of Charles Farley. He helped me through my innumerable crisis with the Vernadsky stage. Thanks Charles! A special thank you to the Fluid Inclusions Gang: Andras, Rocky, Tristan and Steve. Thanks for being not just an excellent group of colleagues but also and most importantly good friends! Thanks to all of the students (grads, undergrads and even Geophysicists!) and faculty of the Geosciences department for the interesting discussions, innumerable parties, field trips, fun hikes and barbeques. Thank you all for making this department such a wonderful and stimulating place to work. A special thank you to the ladies of the administrative office, Caroline, Ellen, Linda and Mary. With their love they made me feel like I was at home. I'll be always grateful to Mrs. Connie Lowe. She paved the way of becoming a VT student and if I receive this degree is because of this wonderful woman who supported me during the past two years. I would like to thank my family and friends in Italy, for their love, encouragement and support. Last but certainly not least, I thank my parents. They have always left me the freedom to follow my dreams, even when this meant moving overseas!! They always believed in me, I would not be here and be what I am without them. Mamma e papa’, grazie infinitamente!!! 


\section{Table of Contents}

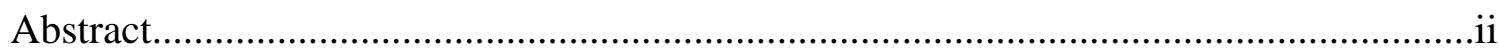

Acknowledgements......................................................................................................ii

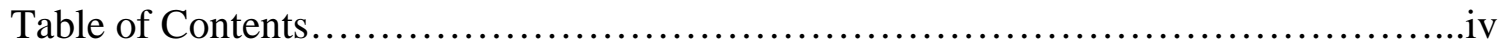

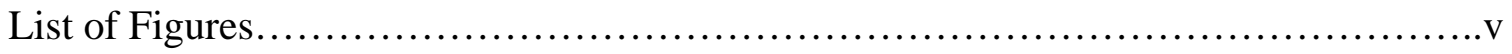

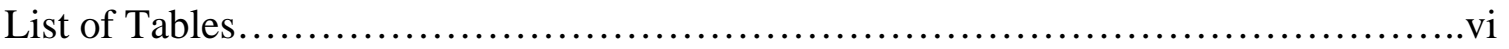

Chapters

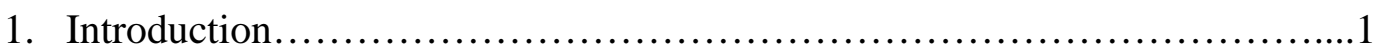

2. Geological Setting.........................................................

3. Samples and methods................................................

3.1 Description of samples and petrography .........................6

3.2 Heating experiments...........................................

3.3 Electron Microprobe Analyses.................................. 8

3.4 Ion Microprobe Analyses......................................... 9

4. Results and Discussion...............................................10

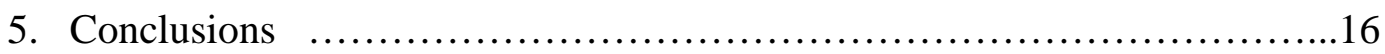

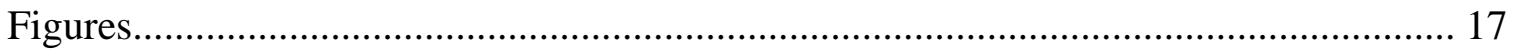

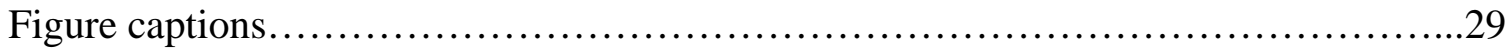

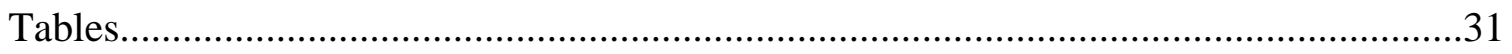

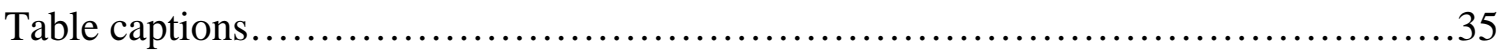

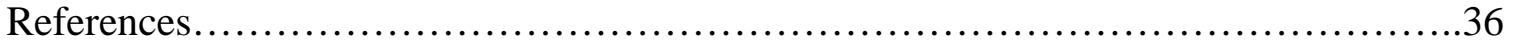

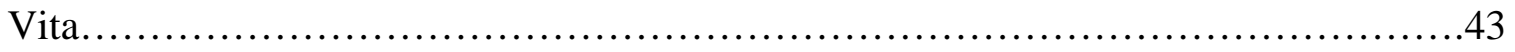




\section{List of Figures}

Figure 1. Schematic map of the geologic setting of Campi Flegrei caldera..............17

Figure 2. Pictures of MI before and after homogenization.............................18

Figure 3. Classification diagram for pyroxene and olivine phenocrysts................19

Figure 4. Rock classification diagram (Le bas et al., 1986)........................................20

Figure 5. Harker variation diagrams..........................................21

Figure 6. Water content of MI...............................................22

Figure 7. Volatile concentrationsin MI.......................................23

Figure 8 . Trace elements systematic: B versus Be............................ 24

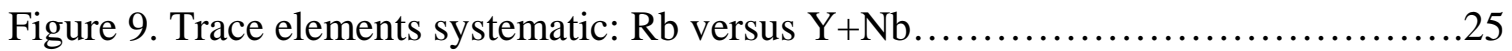

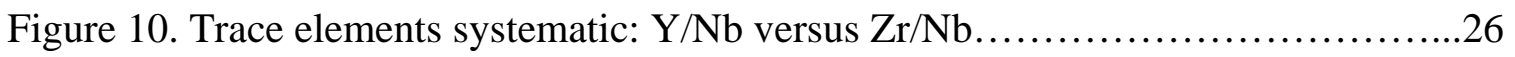

Figure 11. Spider diagram from Pearce et al., 1983....................................................27

Figure 12. Trace elements systematic: Rb versus Cs............................28 


\section{List of Tables}

Table 1a. EMPA and SIMS analyses of MI and host crystals for FR-C1..............31

Table 1b. EMPA and SIMS analyses of MI and host crystals for FR-C2 ...............32

Table 1c EMPA and SIMS analyses of MI and host crystals for Mi1-C1 and C2.........33

Table 2. XRF analyses of CF-FR-C1, CF-FR-C2, CF-Mi-C1 AND CF-Mi1-C2..........34 


\section{CHAPTER 1: INTRODUCTION}

The geochemical evolution of an active volcanic system and identification of the parameters that play a role in determining the style of an eruption are of fundamental importance to understand the past behavior of a magmatic system and to forecast future behavior. Development of geochemical models for volcanic eruption forecasting require information on the volatile content of the magma before an eruption, because volatiles play a major role in controlling the nature and style of eruptive events (Anderson, 1976; Burnham, 1979). The exsolution and expansion of volatiles (especially $\mathrm{H}_{2} \mathrm{O}$ ) provides the mechanical energy that drives explosive volcanic eruptions. The original volatile content of magma can be estimated by analyzing melt inclusions (MI) contained in phenocrysts (Anderson, 1974; Clocchiatti, 1975; Roedder, 1979; Belkin et al., 1985; Sobolev, 1990; Lowenstern, 1994; Anderson, 2003; Wallace, 2005). Moreover, MI may provide information concerning crystallization and mixing histories of magmas and also the conditions of primary melt generation and extraction (Roedder, 1984; Carroll and Holloway, 1994; Lowenstern, 1994; Sobolev, 1996; Marianelli et al., 1999; Danyushevsky et al., 2000; Frezzotti, 2001).

The Campi Flegrei volcanic complex is an active volcanic field in the Neapolitan area (Italy) that has experienced predominantly explosive volcanic activity for more than 60,000 years. The city of Pozzuoli lies close to the Solfatara crater (actually it was built on the deposits of numerous eruptions of the past $10 \mathrm{ka}$ ) while Naples, with 1.5 million inhabitants, is nearby, between Campi Flegrei and Vesuvius. The volcanic risk in this area is significant because of the large population and is a compelling reason to better 
understand the evolution of the Campi Flegrei complex and the mechanisms that lead to explosive eruptions. We studied the products of two eruptions that occurred in Campi Flegrei during the First Cycle: Fondo Riccio (9.5-10.3 ka) and Minopoli 1 (10.3-11.5 ka). Fondo Riccio was an explosive strombolian eruption that occurred near the center of the Campi Flegrei caldera, whereas Minopoli was an explosive hydromagmatic eruption that occurred along the regional fault system in the northern portion of the Campi Flegrei caldera. Data from MI were used to constrain the evolution of major and volatile $\left(\mathrm{H}_{2} \mathrm{O}\right.$, $\mathrm{Cl}, \mathrm{S}$ and $\mathrm{F}$ ) element concentrations, with the goal to reconstruct the crystallization history of the magmas and assess pre-eruptive volatile abundances for the two eruptions. 


\section{CHAPTER 2: GEOLOGICAL SETTING}

The Campi Flegrei Volcanic District lies in the Campanian Plain (CP), between the western side of the Southern Apennine Chain and the eastern border of the Tyrrhenian abyssal plain. Since late Miocene-early Pliocene, the Tyrrhenian Sea has been opening (Scandone, 1979; Doglioni, 1991) and the Calabrian arc has migrated to the SE following rollback of the subducted Ionian plate under Calabria (Selvaggi and Chiarabba, 1995; Piromallo and Morelli, 1997; Gvirtzman and Nur, 2000). Extension in the Tyrrhenian basin was accompanied by contemporaneous compression in the Apennine chain (Meletti et al., 2000). As a result of motions of the Tyrrhenian and Ionian blocks, the CP became a structural depression bordered by NW-SE and NE-SW trending faults (D'Argenio et al., 1973; Ippolito et al., 1975; Hippolyte et al., 1994). Geological, geophysical and petrologic evidence (Selvaggi and Amato, 1992; Serri et al., 1993; Peccerillo, 1999) suggest that subduction of oceanic lithosphere (from the relict Ionian basin) beneath the Apennines occurred concomitant with thinning of the continental lithosphere in the region of the Adriatic Sea, Sicily and North Africa.

The Campi Flegrei caldera (Fig, 1) is one of the most active volcanic systems in the Mediterranean region. The area is known for intense hydrothermal activity, frequent earthquakes and bradyseismic events that occurred between1969-1972 and 1982-1984. The area has been volcanically active for $60 \mathrm{ka}$ (Pappalardo et al., 2002) and many studies have been devoted to understanding its activity (Di Girolamo et al., 1984; Rosi and Sbrana, 1987; Barberi et al., 1991; Pappalardo et al., 1999; De Vivo et al., 2001; Rolandi et al., 2003). At Campi Flegrei, numerous eruptions from multiple sources have 
produced lava and pyroclastic deposits, including several lava dome structures. Some authors (Rosi and Sbrana, 1987; Orsi et al., 1996) relate the origin of Campi Flegrei either to the eruption of the Campanian Ignimbrite (CI) (39 ka, De Vivo et al., 2001), or to the Neapolitan Yellow Tuff (NYT) (15 ka, Deino et al., 2004). An interpretation that considers the eruption of the $\mathrm{CI}$ to be a unique event originating in the Campi Flegrei caldera has been questioned by De Vivo et al. (2001) and Rolandi et al. (2003). These authors describe a sequence of eruptive events from fractures activated along the neotectonic Apennine fault system parallel to the Tyrrhenian coastline. These events, of ignimbritic origin, lasted from $>300 \mathrm{ka}$ to $19 \mathrm{ka}$ and are not confined to a unique volcanic center in Campi Flegrei (Rosi and Sbrana, 1987; Orsi et al., 1996). Only the Neapolitan Yellow Tuff (NYT) (15ka, Deino et al., 2004) erupted within Campi Flegrei, whereas the CI (39 ka, De vivo et al., 2001) has a much wider source area (Rolandi et al., 2003). According to Pappalardo et al. (2002), the time between the CI and NYT eruptions is characterized by a large number of significantly less powerful events. Volcanism in this interval is poorly defined, primarily because of limited exposure due to cover by younger deposits, restriction to submarine exposure, and intense urbanization. Since the NYT eruption the edge of the caldera has been the site of at least 65 eruptions during three periods of activity $(15.0-9.5 ; 8.6-8.2$; and $4.8-3.8 \mathrm{ka})$. These eruptions were separated by quiescent periods marked by two widespread paleosoils (Di Vito et al., 1999). During each eruptive period, eruptions were separated by short-time intervals, on the order of tens of years. The last eruption in 1538 formed the Monte Nuovo cone (Di Vito et al., 1987) after 3.4 ka of quiescence. 
Campi Flegrei eruptions were mostly explosive with variable degrees of magma/water interaction; only a few events were effusive. The volcanic products range from trachybasalt to alkali-trachyte and phono-trachyte, and are characterized by variable Sr-Nd-Pb-B isotope ratios (D’Antonio et al., 1999a; Pappalardo et al., 2002; Tonarini et al., 2004) and involve different magma types (i.e. from different sources and/or with different history) or source processes. 


\section{CHAPTER 3: SAMPLES AND METHODS}

\subsection{Description of samples and petrography}

Products from two eruptions that occurred in the First Epoch were studied. The Fondo Riccio eruption occurred at $9.5 \mathrm{ka}$ from an eruptive center on the western side of the Gauro volcano, near the center of the Phlegraean caldera. The eruption was explosive, with strombolian character. The eruptive deposits are composed of coarse scoria beds with subordinate coarse-ash beds and overlay Montagna Spaccata tephra and are in turn overlain by paleosol A (Di Vito et al., 1999).

The Minopoli 1 eruption was a magmatic eruption, with hydromagmatic phases, that occurred at $11.1 \mathrm{ka}$, along a regional fault system in the northern sector of the Phlegraean caldera. The eruptive products are composed of alternating pumice lapilli fallout and mainly massive ash fallout, and less abundant cross laminated ash surge beds. The deposits overlay Pomici Principali and are overlain by Montagna Spaccata (Di Vito et al., 1999).

Sample CF-FR-C1 is a scoria and sample CF-FR-C2 is a lava bomb from the Fondo Riccio unit. Both samples are porphyritic latite, with abundant crystals in a glassy, vesicular groundmass, and were deposited between 9.5 and $10.3 \mathrm{ka}$ (Di Vito et al., 1999).

The bulk rock contains less than $10 \%$ phenocrysts, which include clinopyroxene, olivine and biotite with subordinate plagioclase and magnetite. In thin section clinopyroxene and plagioclase are found in small clots; these minerals also occur among microlites. Silicate $\mathrm{MI}$ in olivine and pyroxene phenocrysts from sample FR-C1 and in clinopyroxenes for 
the sample FR-C2 were studied. For the Minopoli 1 unit, sample MI1-C1 is a scoria and sample MI1-C2 is a cohesive scoria sampled along the caldera rim, and was likely erupted during the final magmatic stage of the eruption. The deposits include scoria and ash layers. Both samples are porphyritic trachybasalt and range from 11.1 and $10.3 \mathrm{ka}$ (Di Vito et al, 1999). The bulk rock contains about $20 \%$ phenocrysts, which include clinopyroxene, olivine and biotite. Silicate MI in olivine and pyroxene from Mi1-C1 and in clinopyroxene from MI1-C2 were studied.

The abundance of MI varies from crystal to crystal in the same sample. Melt inclusions consist of silicate glass, generally devitrified, with a shrinkage bubble and daughter crystals (usually apatite or Fe/Ti oxides). MI generally have elongated rectangular shapes and range from 30 to $80 \mu \mathrm{m}$ (most between 20 and $50 \mu \mathrm{m}$ ) (Fig. 2). Rock samples were hand crushed and phenocrysts were hand picked, mounted on a glass slide, and doubly polished to improve the optical clarity during microscope heating experiments.

\section{$\underline{3.2 \text { Heating experiments }}$}

MI from Fondo Riccio and Minopoli 1 were partially or totally recrystallized when found and required heating and quenching to obtain a homogeneous glass. Heating experiments have been carried out at the Department of Geosciences at Virginia Tech (Blacksburg, USA) using the heating stage designed and built at the Vernadsky Institute, Moscow (Sobolev and Slutski, 1984). All the experiments were conducted in controlled (inert gas) atmosphere to avoid oxidation of the crystal according to the procedure 
described in Danyushevsky et al. (2000) and Lima (2000). The precision of temperature measurements is $\pm 3^{\circ} \mathrm{C}$ at $1200^{\circ} \mathrm{C}$ (measured by thermocouple), based on calibration using known melting points of $\mathrm{Ag}\left(938^{\circ} \mathrm{C}\right)$ and $\mathrm{Au}\left(1064^{\circ} \mathrm{C}\right)$. The inclusions were heated until all solid phases disappeared. Total homogenization (i.e. disappearance of the bubble) was not attempted to avoid decrepitation. The partial homogenization temperature $\left(T_{h}\right)$ thus represents a minimum estimate of the trapping temperature.

\subsection{Electron Microprobe Analyses}

After quenching, single crystals were mounted with epoxy on transparent polycarbonate rods and polished according to the technique described by Thomas and Bodnar (2002) to expose MI. MI were analyzed with a Cameca SX/50 Microprobe at University of Rome "La Sapienza" (IGAG-CNR, Rome, Italy) and at Virginia Tech (Blacksburg, USA). Analyses were performed at $15 \mathrm{kV}$, using a current of $10 \mathrm{nA}$ with a defocused beam diameter of $10 \mu \mathrm{m}$ and counting time 10 seconds, as recommended by Morgan and London (1996). Relative one-sigma precision is estimated to be 1 to $2 \%$ for major elements and 5 to $10 \%$ for minor elements. In each analytical run, alkalis were counted first, and no correction has been made for Na loss. Test runs made prior to the beginning of the analysis on synthetic and natural glass standards of known composition showed no significant alkali migration under the specified analytical conditions. Two points were analyzed in larger MI, whereas only one point was analyzed in smaller inclusions $(<10 \mu \mathrm{m})$. When no significant difference in composition was detected, an average of the two analyses was used. If the two analyses were significantly different the 
results were discarded. If just one spot was possible, a comparison between the obtained data and data for other MI in the same sample was made to test for consistency. Note, however, that two or more analyses were obtained on $\sim 90 \%$ of the MI. Host phenocrysts were analyzed at distances of about $20 \mu \mathrm{m}$ from MI with accelerating voltage of $15 \mathrm{kV}$ and beam current of $10 \mathrm{nA}$.

\section{$\underline{3.4 \text { Ion Microprobe Analyses }}$}

Selected MI were analyzed for $\mathrm{H}$ (reported as $\mathrm{H}_{2} \mathrm{O}$ ), $\mathrm{Li}, \mathrm{Be}, \mathrm{B}, \mathrm{Rb}, \mathrm{Sr}, \mathrm{Y}, \mathrm{Zr}, \mathrm{Nb}$, $\mathrm{Cs}, \mathrm{Ce}, \mathrm{Sm}, \mathrm{Dm}, \mathrm{Yb}$, Th and U by Secondary Ion mass Spectrometry (SIMS) at the Woods Hole Oceanographic Institution, using techniques detailed by Shimizu and Hart (1982) and Webster et al. (1996). Accelerating potential was $10 \mathrm{kV}$ and beam current was 1-2 nA. The inclusions were analyzed in one spot, five times each in depth profile mode. Precision and accuracy were monitored with NBS (National Bureau of Standards) reference glasses NBS 610. Results on the NBS glasses are similar and within 5\% of the accepted values; $\mathrm{H}_{2} \mathrm{O}$ concentrations are reproducible to \pm 0.3 to $0.4 \mathrm{wt} \%$ and trace elements to 5 to $15 \%$ (for more details see Webster et al., 2001). 


\section{CHAPTER 4: RESULTS AND DISCUSSIONS}

Fondo Riccio olivine compositions range from $\mathrm{Fo}_{84}$ to $\mathrm{Fo}_{87}$, while Minopoli 1 olivines range from $\mathrm{Fo}_{77}$ to $\mathrm{Fo}_{78}$ (Fig. 3). Clinopyroxene compositions fall in the diopside-salite field ( $\left.\mathrm{Wo}_{44-48}, \mathrm{Fs}_{5-19}\right)$ and $\mathrm{Mg} \#$ (calculated based on total $\mathrm{Fe}$ ) varies from about 73.4 to 88.6 for Fondo Riccio samples (with a compositional gap between 78 and 83) and from about 85.1 to 89.9 for Minopoli 1 samples. Clinopyroxenes are low-Ti, which is a characteristic of "HKS"- type lavas of the Roman Comagmatic Province (Cundari and Fergusson, 1982).

Homogenization temperatures of MI in clinopyroxene and olivine from the scoria of Fondo Riccio (FR-C1) average $1135 \pm 3^{\circ} \mathrm{C}$ and $1155 \pm 3^{\circ} \mathrm{C}$, respectively, whereas $\mathrm{MI}$ in clinopyroxene from the bomb sample (FR-C2) average $1159 \pm 3{ }^{\circ} \mathrm{C}$. Homogenization temperatures of Minopoli $1 \mathrm{MI}$ in clinopyroxenes average $1132 \pm 3^{\circ} \mathrm{C}$ and those in olivine average $1145 \pm 3^{\circ} \mathrm{C}$.

The maximum temperature achieved during heating experiments does not equal the trapping temperature because a bubble still remained in the inclusions. MI compositions can be depleted in the host mineral components if the maximum temperature of heating is below the trapping temperature. Thus, the concentrations of most elements in the quenched MI may not reflect their original values in the trapped melt. However, ratios of elements that are incompatible in the host, and also concentrations of elements that are present at similar levels in the melt and the host, should not be significantly affected by over- or under-heating. Moreover, Fedele et al. (2003) have shown that compositions of MI obtained from inclusions that were heated until all of the solids had melted (with the 
bubble still present) and quenched were in good agreement with melt compositions predicted by the MELTS program (see also Thomas et al, 2002).

Representative compositions of MI (average values) hosted in Fondo Riccio clinopyroxene and olivine are shown together with MI size, maximum temperature $\left(\mathrm{T}_{\text {run }}\right)$ and host crystal Mg\# in Table 1a (FR-C1) and 1b (FR-C2). Representative compositions of MI from Minopoli 1 are shown in Table 1c. All MI are characterized by analytical totals $<100$. This is interpreted to reflect the presence of $\mathrm{H}_{2} \mathrm{O}$ in the MI, as confirmed by secondary ion mass spectrometry (SIMS) analyses that show average $\mathrm{H}_{2} \mathrm{O}$ contents between 3.3 - $6.9 \mathrm{wt} \%$ for Fondo Riccio samples and between 1.3-5.2 wt \% for Minopoli 1 samples (Tables 1a-c).

MI from Fondo Riccio show a broad range for $\mathrm{SiO}_{2}$ (46.8 - $\left.59.3 \mathrm{wt} \%\right), \mathrm{CaO}(3.66$ $12.4 \mathrm{wt} \%), \mathrm{Na}_{2} \mathrm{O}(1.3-3.7 \mathrm{wt} \%)$ and $\mathrm{K}_{2} \mathrm{O}+\mathrm{Na}_{2} \mathrm{O}(4.19$ - $9.73 \mathrm{wt} \%)$. Conversely, MI from Minopoli 1 show narrow ranges for $\mathrm{SiO}_{2}(49.6-51.8 \mathrm{wt} \%), \mathrm{CaO}(7.6-13.3 \mathrm{wt} \%), \mathrm{Na}_{2} \mathrm{O}$ (1.0-1.8 wt\%) and $\mathrm{K}_{2} \mathrm{O}+\mathrm{Na}_{2} \mathrm{O}(4.19-9.73 \mathrm{wt} \%)$ as shown in Tables 1a-c.

On the total alkali-SiO 2 classification diagram (Fig.4; Le Bas et al., 1986) the Fondo Riccio bulk-rock composition is in the latite field. Fondo Riccio MI data show two trends: from latite to trachyte for MI in Fe-rich diopside (sample CF-FR-C1) and from trachybasalt to shoshonite for MI in both Mg-rich diopside (sample CF-FR-C2) and olivine (sample CF-FR-C1). The Minopoli 1 bulk-rock composition is in the trachyandesite field, whereas MI data show two different compositions: basalt for MI in clinopyroxenes from the lower unit (Mi1-C1) and trachybasalt for MI in olivine (Mi1-C1) and clinopyroxenes from the upper unit (Mi1-C2). Except for clinopyroxene in FR-C1, MI are generally less evolved than the corresponding host rock. In particular, MI in 
olivine from CF-FR-C1 scoria show the same, less evolved composition as MI in clinopyroxene from CF-FR-C2 bomb sample. The Fondo Riccio bulk rock is depleted in $\mathrm{K}_{2} \mathrm{O}$ (not shown in the variation diagrams) and enriched in $\mathrm{TiO}_{2}$ and $\mathrm{Na}_{2} \mathrm{O}$ compared with MI with similar Mg\# hosted in clinopyroxene from the CF-FR-C1 scoria sample. Harker diagrams showing major element concentrations of $\mathrm{MI}$ as a function of $\mathrm{SiO}_{2}$ show a wider range in composition in Fondo Riccio samples than Minopoli 1 (Fig. 5). MI in clinopyroxene and olivine from both samples show decreasing $\mathrm{Al}_{2} \mathrm{O}_{3}$ (Fig. 5a) and $\mathrm{Na}_{2} \mathrm{O}$ (Fig. 5f) and increasing $\mathrm{FeO}^{\text {tot }}$ (Fig. 5b), $\mathrm{TiO}_{2}$ (Fig. 5c), $\mathrm{MgO}$ (Fig. 5d) and $\mathrm{CaO}$ (Fig. 5e) with decreasing $\mathrm{SiO}_{2}$. These trends are consistent with crystallization of olivine and clinopyroxene from alkali basalt magma. In particular, the trends described above suggest earlier crystallization of olivine in the CF-FR-C1 sample and clinopyroxene in the CFFR-C2 sample compared with the timing of crystallization of clinopyroxene in the CFFR-C1 scoria sample. The $\mathrm{TiO}_{2}$ contents of these MI are consistent with the low Ticontents of lavas from the Roman Comagmatic Province. To explain Ti enrichment in the bulk rock compared with MI (whose compositions should represent the melt composition before the eruption), the studied rocks would have to contain about $60 \%$ groundmass and $\approx 40 \%$ phenocrysts (clinopyroxene, olivine, feldspar and biotite), which is a higher phenocryst abundant than that observed in thin sections. If we assume that the groundmass has a composition similar to $\mathrm{MI}$ in more evolved clinopyroxene, then $\mathrm{TiO}_{2}$ bulk-rock contents are compatible with analyzed values (Table 1a-c).

It is more difficult to explain $\mathrm{Na}_{2} \mathrm{O}$ enrichment in the bulk rock, even though $\mathrm{Na}_{2} \mathrm{O}$ in the melt is expected to increase during crystallization ( $\mathrm{Na}$ behaves as an incompatible element during magma fractionation). We also observe a greater $\mathrm{Na}$ 
enrichment in Fondo Riccio bulk rock compared to Minopoli1 bulk rock. Hydrothermal activity is present in the vicinity of the Fondo Riccio eruption and, as explained for similar behavior at Vesuvius (Lima et al., in press), $\mathrm{Na}_{2} \mathrm{O}$ enrichment in the bulk rock most likely represents the effects of hydrothermal fluids. During explosive eruptions associated with decompression during magma ascent, the reaction of $\mathrm{NaCl}$ with $\mathrm{H}_{2} \mathrm{O}$ at low pressure $(<300$ bars) becomes important and hydrolysis reactions produce $\mathrm{HCl}$ and $\mathrm{NaOH}$ that remain preferentially in the melt (Veksler, 2004). Note that the trend in $\mathrm{Na}$ enrichment observed here is the opposite of that observed during subsolidus hydrothermal alteration of melt inclusions in porphyry copper systems (Student and Bodnar, 2004).

The volatile content of MI as a function of $\mathrm{SiO}_{2}$ for the two eruptions are shown in Fig.6. The $\mathrm{SO}_{2}$ content of $\mathrm{MI}$ in clinopyroxene from scoria $(\mathrm{C} 1)$ varies between 0.04 and $0.29 \mathrm{wt} \%$; and from 0.25 to $0.40 \mathrm{wt} \%$ for $\mathrm{MI}$ in olivine from the scoria $(\mathrm{C} 1)$ and from 0.13 to $0.34 \mathrm{wt} \%$ for $\mathrm{MI}$ in clinopyroxene from the bomb (C2). For Minopoli $1 \mathrm{MI}, \mathrm{SO}_{2}$ varies from 0.09 to $0.11 \mathrm{wt} \%$ for clinopyroxene from $\mathrm{C} 1$, from 0.21 to $0.34 \mathrm{wt} \%$ for $\mathrm{MI}$ in olivine from $\mathrm{C} 1$, and from 0.31 to $0.37 \mathrm{wt} \%$ for $\mathrm{MI}$ in clinopyroxene from $\mathrm{C} 2$. The $\mathrm{SO}_{2}$ concentration decreases with increasing $\mathrm{SiO}_{2}$, consistent with degassing during magma crystallization. MI hosted in clinopyroxene from FR-C1 shows little variation in $\mathrm{S}$ content as a function of $\mathrm{SiO}_{2}$. One Minopoli $1 \mathrm{MI}$ containing approximately 48 wt.\% $\mathrm{SiO}_{2}$ and $0.91 \mathrm{wt} \% \mathrm{SO}_{2}$ falls well outside the range of all other values. This data point was not discarded because it represents the average of two nearly identical analyses on the same MI. 
Decreasing $\mathrm{P}_{2} \mathrm{O}_{5}$ with increasing $\mathrm{SiO}_{2}$ (Fig. 6b) is consistent with apatite crystallization during magma evolution. No systematic variation in F is observable for the two samples (Fig. 6c).

Chlorine abundance (Fig. 6d) in the Fondo Riccio MI ranges from 0.32 to $0.72 \mathrm{wt}$ $\%$ in $\mathrm{MI}$ in clinopyroxene from the scoria (mean of $0.54 \mathrm{wt} \%$ ), whereas $\mathrm{Cl}$ shows much less variation in $\mathrm{MI}$ in clinopyroxene from the bomb sample (CF-FR-C2) (between 0.42 and $0.57 \mathrm{wt} \%$ with a mean of $0.49 \mathrm{wt} \%$ ) and in MI in olivine from CF-FR-C1 sample (between 0.42 and $0.47 \mathrm{wt} \%$ with a mean of $0.44 \mathrm{wt} \%$ ). Minopoli 1 MI show a smaller variation in $\mathrm{Cl}$ content compared to Fondo Riccio. $\mathrm{Cl}$ varies from 0.34 to $0.2 \mathrm{wt} \%$ in $\mathrm{MI}$ in clinopyroxenes from Mi1-C1 (mean $0.27 \mathrm{wt} \%$ ), $0.43 \pm 0.01 \mathrm{wt} \%$ for $\mathrm{MI}$ in olivine from Mi1-C1 and from 0.39 to $0.42 \mathrm{wt} . \%$ for MI in clinopyroxene from Mi1-C2. These results suggest that the magma that generated the Fondo Riccio scoria phenocrysts was not affected by $\mathrm{Cl}$ loss. The $\mathrm{Cl}$ content is slightly higher in more evolved $\mathrm{MI}$ than in less evolved MI for Fondo Riccio samples (Fig. 6d), whereas such a trend is not observed for Minopoli 1 MI.

The average $\mathrm{H}_{2} \mathrm{O}$ content, measured by EMPA, is consistent with the $\mathrm{H}_{2} \mathrm{O}$ obtained by SIMS (Fig.7). In general, less evolved MI have higher concentrations of water and Fondo Riccio MI are enriched in $\mathrm{H}_{2} \mathrm{O}$ compared to Minopoli 1 MI (even though the concentrations overlap). This may explain the more explosive character of the Fondo Riccio eruption compared to the Minopoli 1 eruption.

In order to better understand the origin of the magma that fed these two eruptions, trace element systematics have been examined. Compositions of MI from both eruptions have $\mathrm{B}$ and $\mathrm{Be}$ concentrations that fall close to the $\mathrm{B} / \mathrm{Be}=4$ line that divides rocks that 
originate in volcanic arc environments and those that are sourced in an ocean island volcanic setting (Fig. 8). $\mathrm{Rb}$ versus $\mathrm{Y}+\mathrm{Nb}$ systematics of MI straddle the boundary between rocks associated with "within plate" volcanism and those generated in volcanic arc settings (Fig. 9). $\mathrm{Y} / \mathrm{Nb}$ versus $\mathrm{Zr} / \mathrm{Nb}$ systematics of $\mathrm{MI}$ are consistent with magmas generated in the upper continental crust, but also point towards the island arc environment (Fig. 10). An upper continental crust origin for the MI is also suggested by the Sr, Rb, Th, Nb, Ce, Zr, Sm, Y and Yb spider diagram (Pearce, 1984) (Fig.11).

The relationship between $\mathrm{Rb}$ and $\mathrm{Cs}$ for MI from Somma-Vesuvius (SV) and the Campanian Ignimbrite (CI) (shaded areas) from Webster et al., 2003 are compared with MI from this study in Fig. 12. The data suggest that Fondo Riccio and Minopoli 1 eruptive products were more likely generated from a magma similar to that which fed Somma Vesuvius rather than that which produced the Campanian Ignimbrite rocks.

The trace element data presented above are consistent with the tectonic setting of the Neapolitan area, and with the possible involvement of slab-derived fluids, as suggested by Piochi et al. (2005). 


\section{CHAPTER 5: CONCLUSIONS}

MI from Fondo Riccio and Minopoli 1 show systematic variations in composition compared to the bulk-rock compositions. Major and trace element composition of MI are consistent with an evolving magma chamber in which olivine and clinopyroxenes are crystallizing. The composition of MI in olivine from Fondo Riccio scoria (CF-FR-C1) is similar to $\mathrm{MI}$ in clinopyroxene from the bomb (CF-FR-C2). Except for clinopyroxene in Fondo Riccio C1, MI are generally less evolved than the corresponding host rock. Major and trace elements in Fondo Riccio MI show a wider variation compared to those in Minopoli 1 MI. This could be interpreted to indicate that the Fondo Riccio magma residence time was longer compared to the Minopoli 1 magma. $\mathrm{Na}_{2} \mathrm{O}$ enrichment in the Fondo Riccio bulk rock represents the effects of hydrothermal activity in the volcanic system before and during the explosive eruptions (see, De Vivo and Lima, in press).

The concentration of $\mathrm{SO}_{2}$ and $\mathrm{H}_{2} \mathrm{O}$ is higher in less evolved $\mathrm{MI}$, whereas $\mathrm{Cl}$ is higher in more evolved MI. F shows no obvious variation as a function of $\mathrm{SiO}_{2}$. The generally higher volatile contents of Fondo Riccio MI are consistent with the more explosive character of this eruption compared to Minopoli 1. Trace element data suggest a combination of arc volcanic and upper continental crust magma as the source for the Fondo Riccio and Minopoli 1 eruptions. Major and trace element systematics suggest that these two eruptions, which occurred at different times, were sourced from a single batch of magma that has evolved with time. The smaller range in compositions of the Minopoli 1 MI compared to the Fondo Riccio samples suggest a shorter residence time for Minopoli compared to Fondo Riccio magma. 


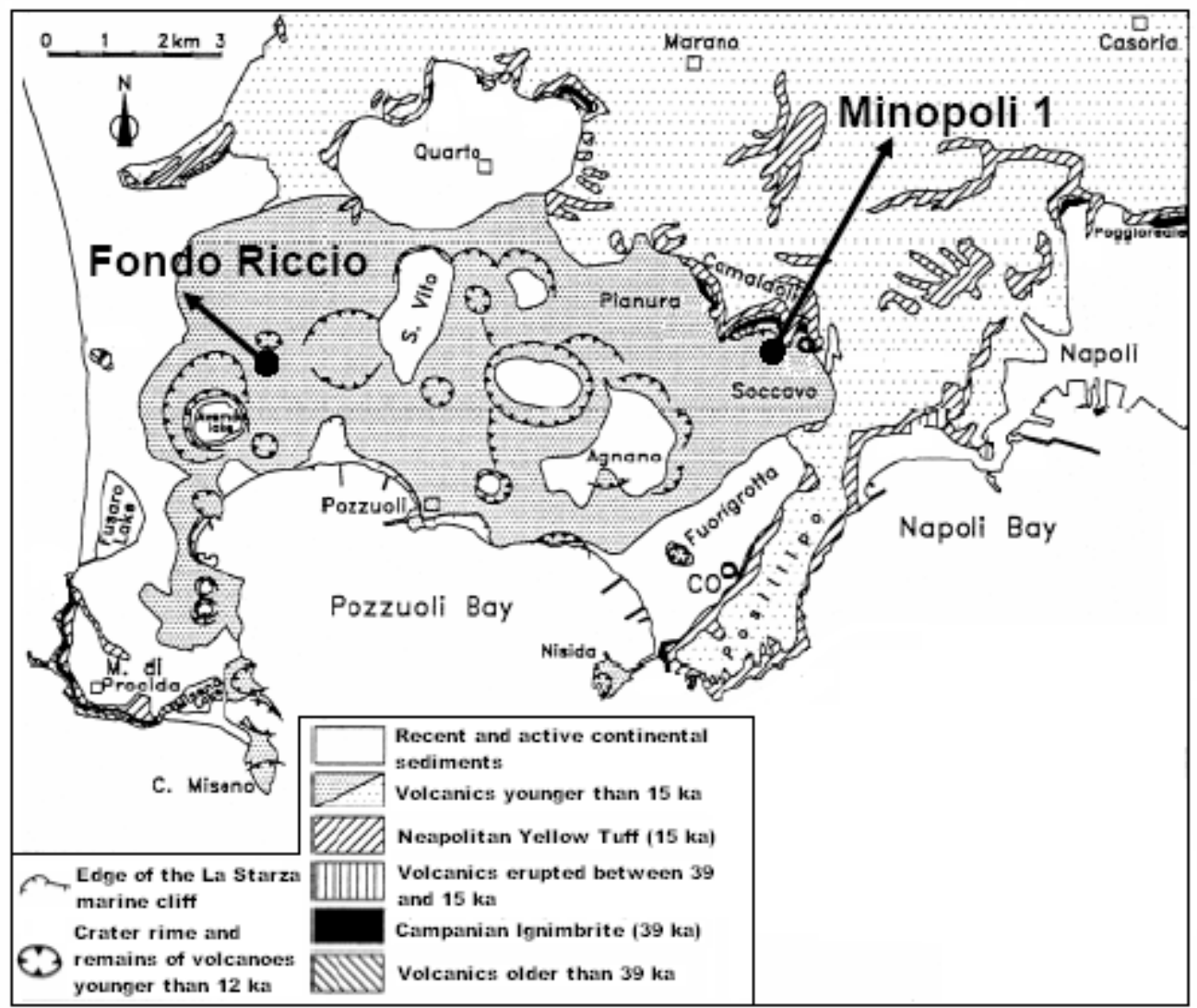

Fig.1 


\section{Before heating}

After heating

$40 \mu \mathrm{m}$

Fig. 2 

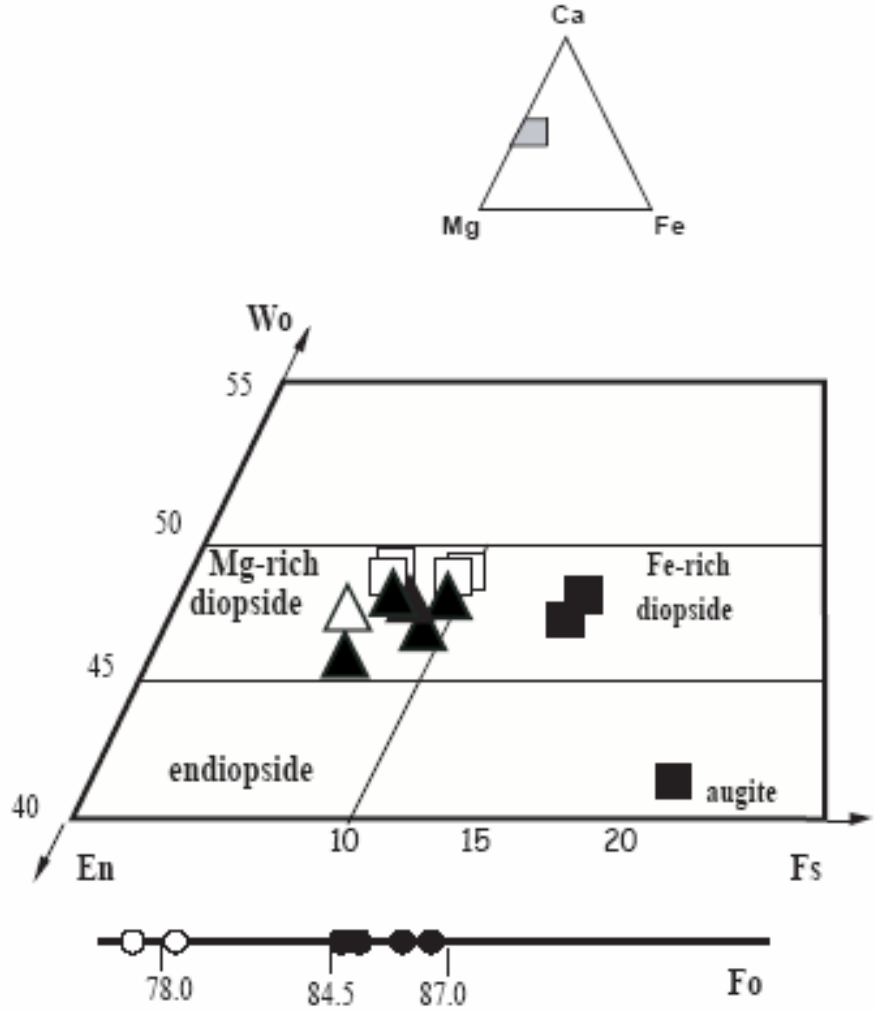

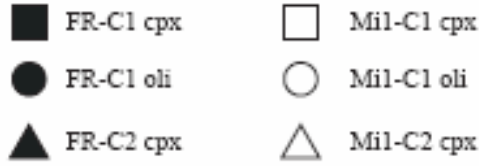

Fig.3 


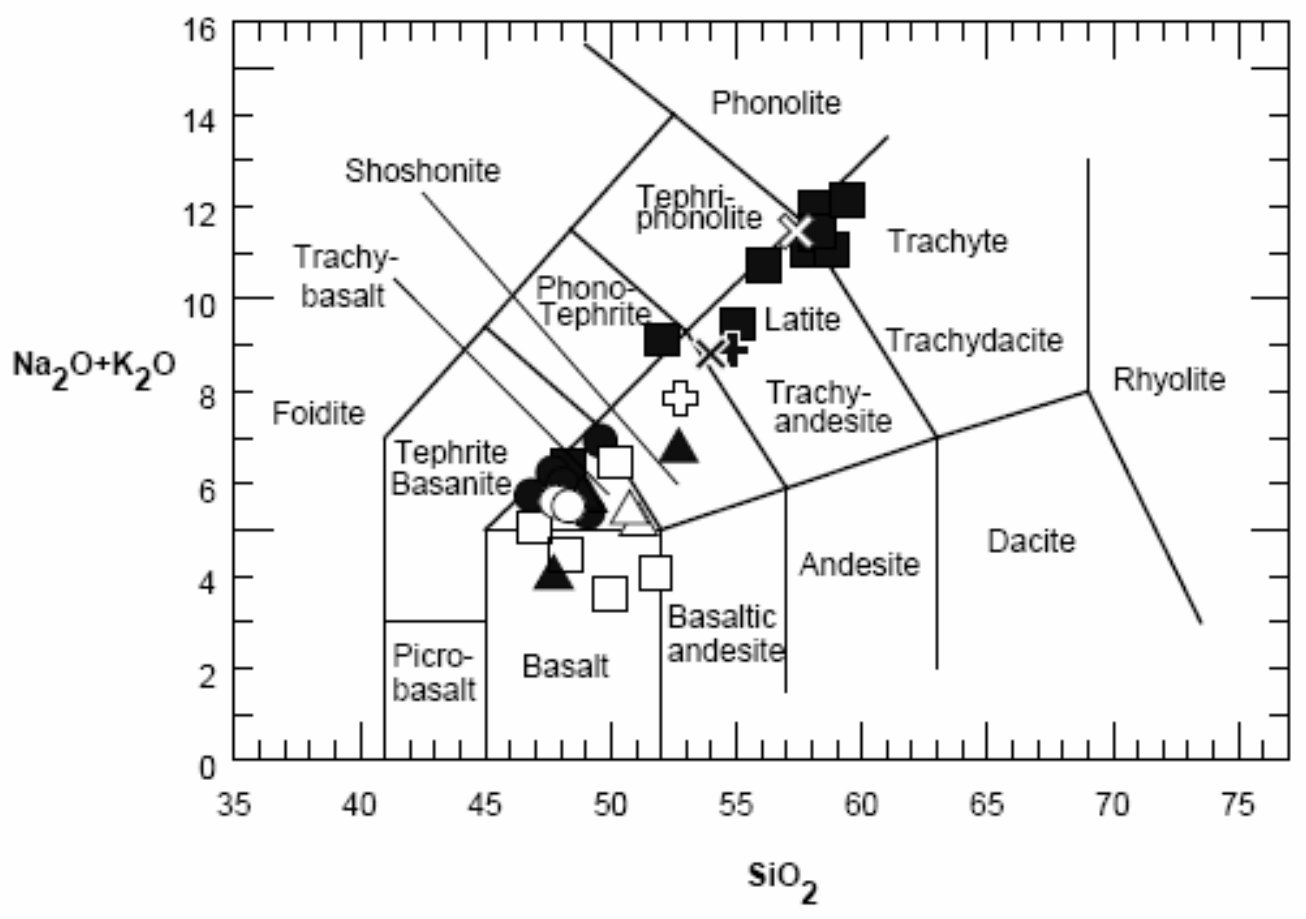

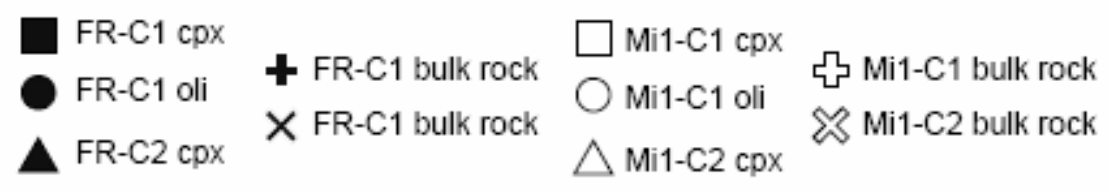

Fig 4 

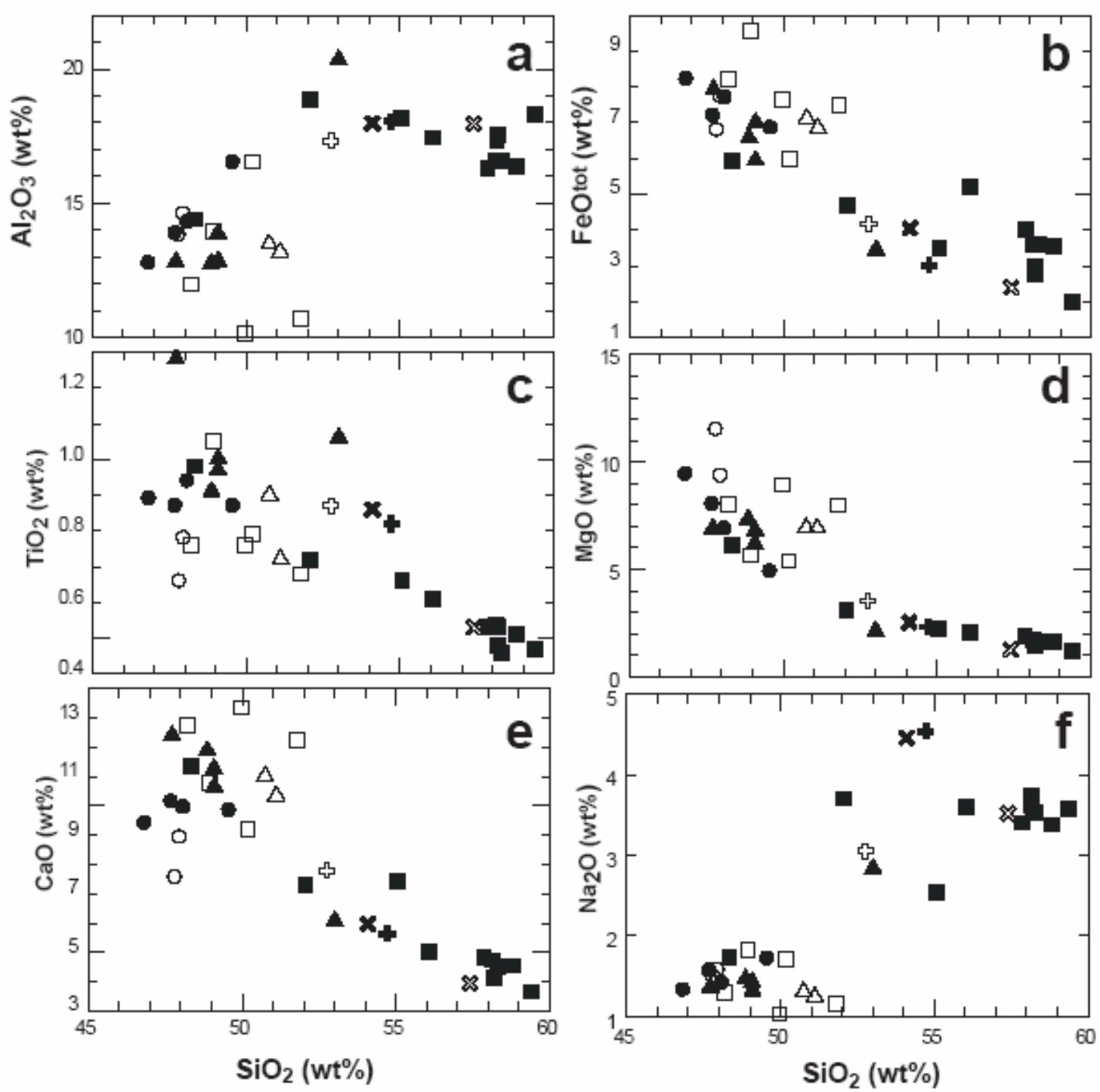

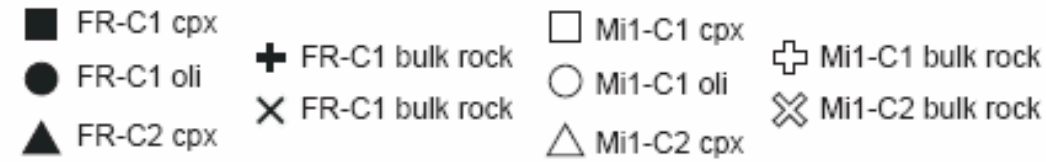

Fig.5 


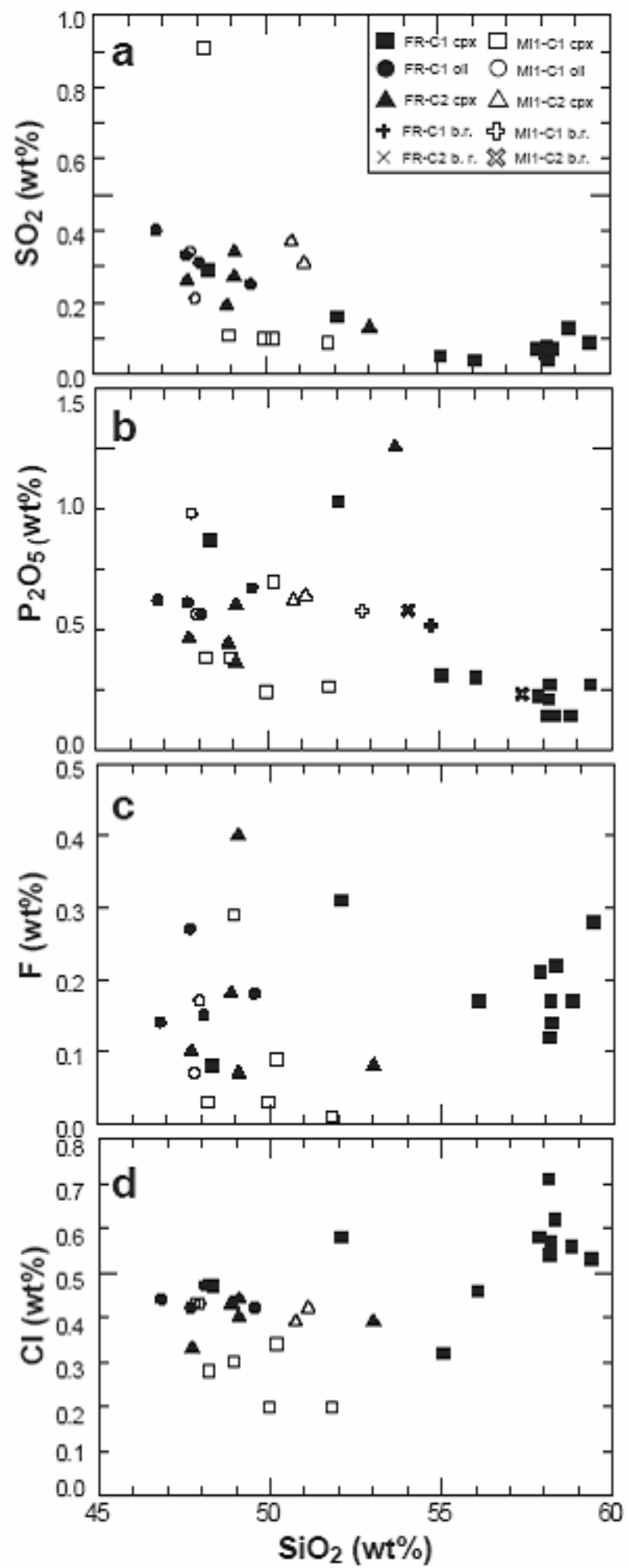

Fig.6 


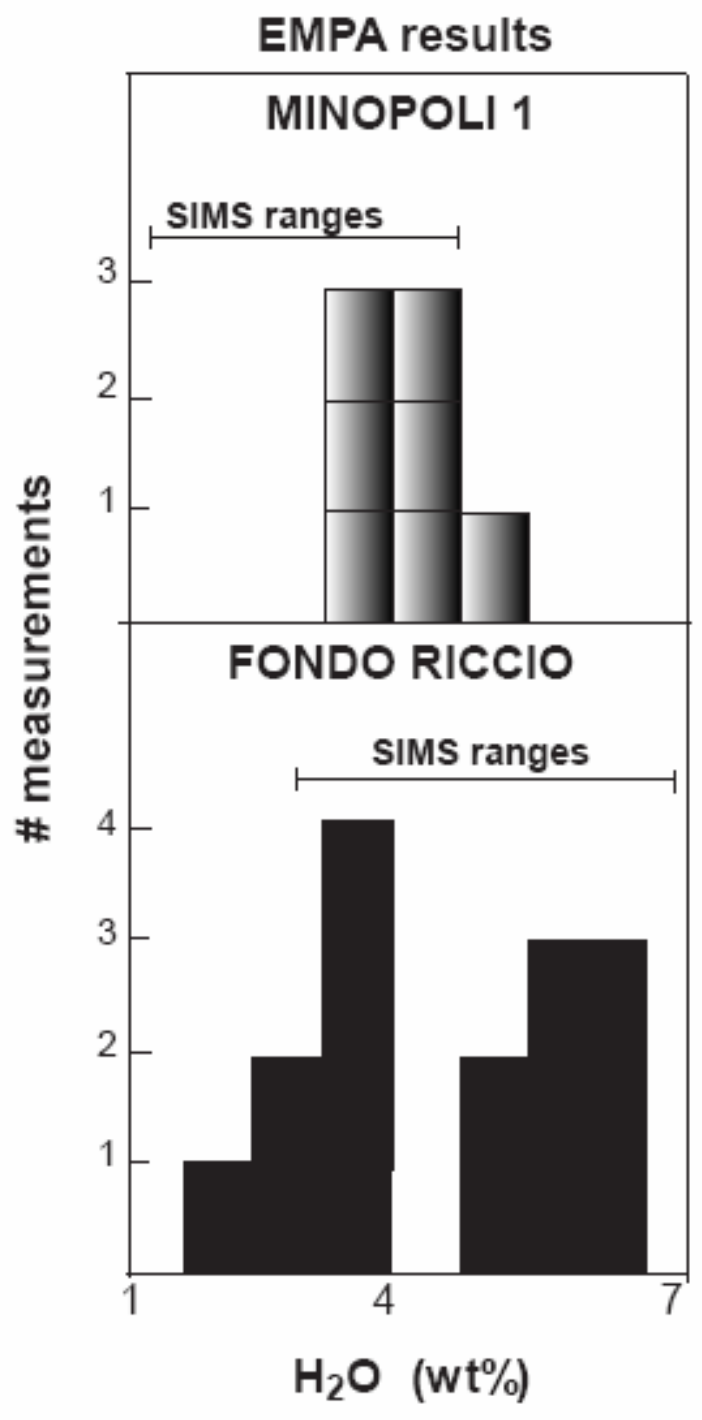

Fig.7 


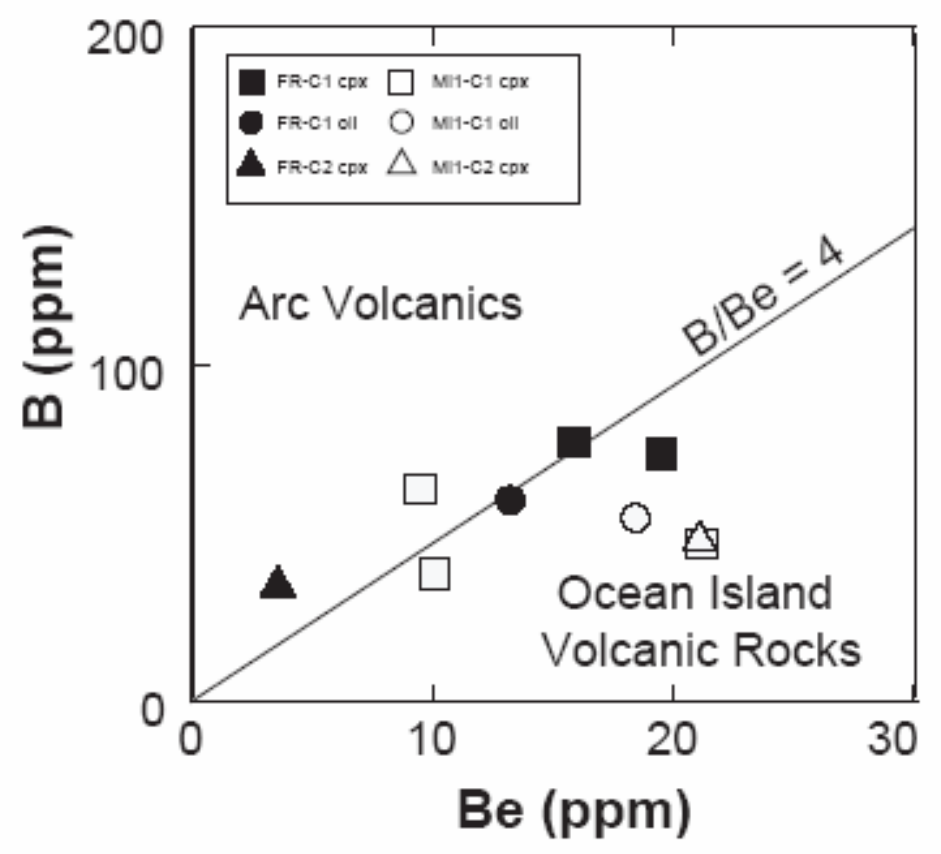

Fig.8 


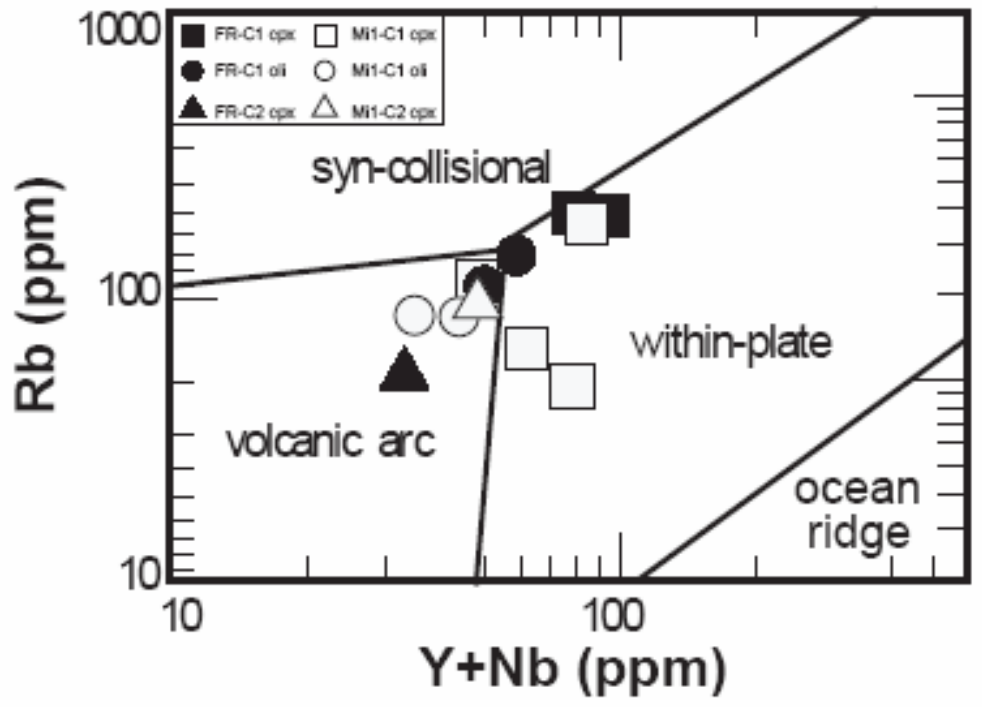

Fig.9 


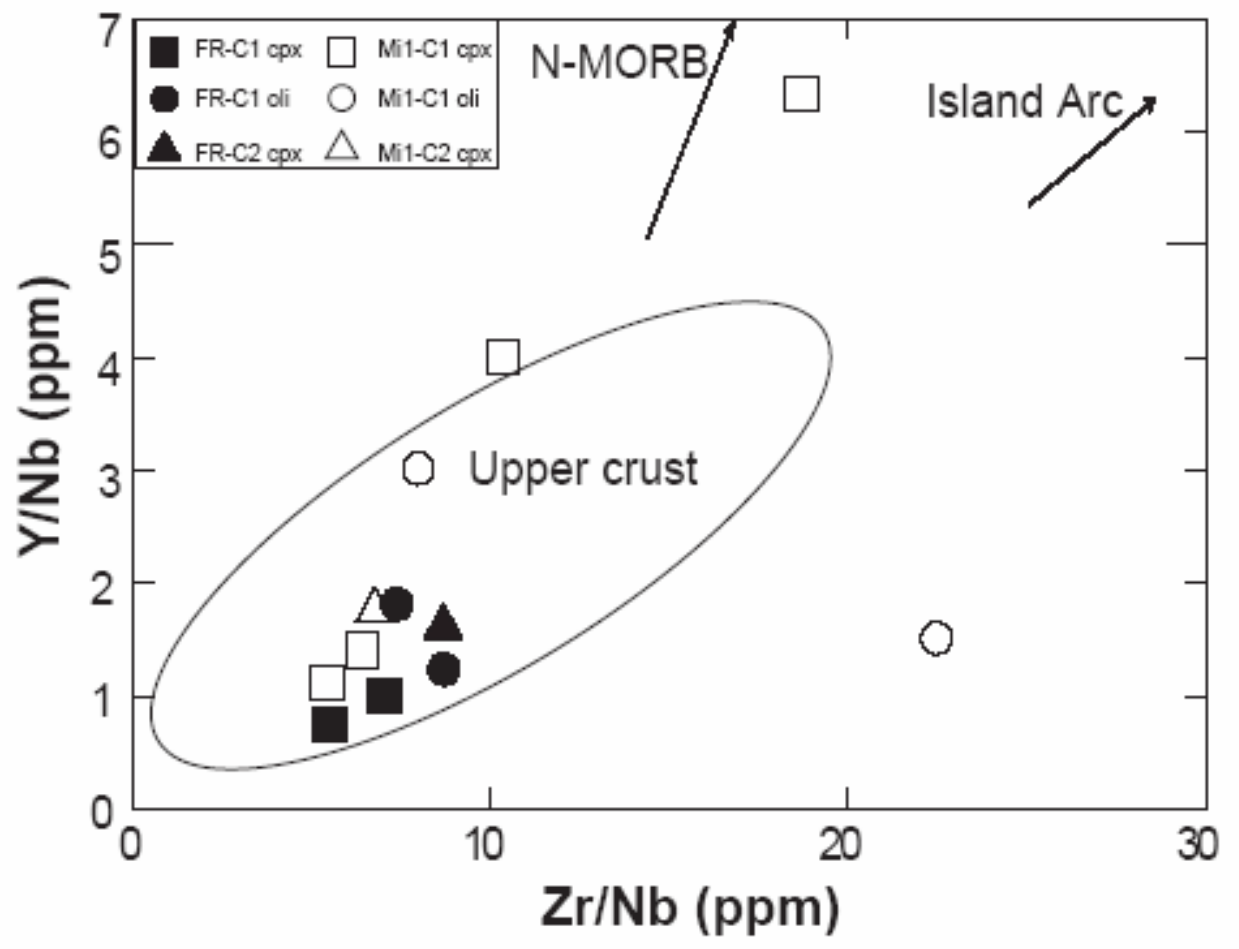

Fig.10 


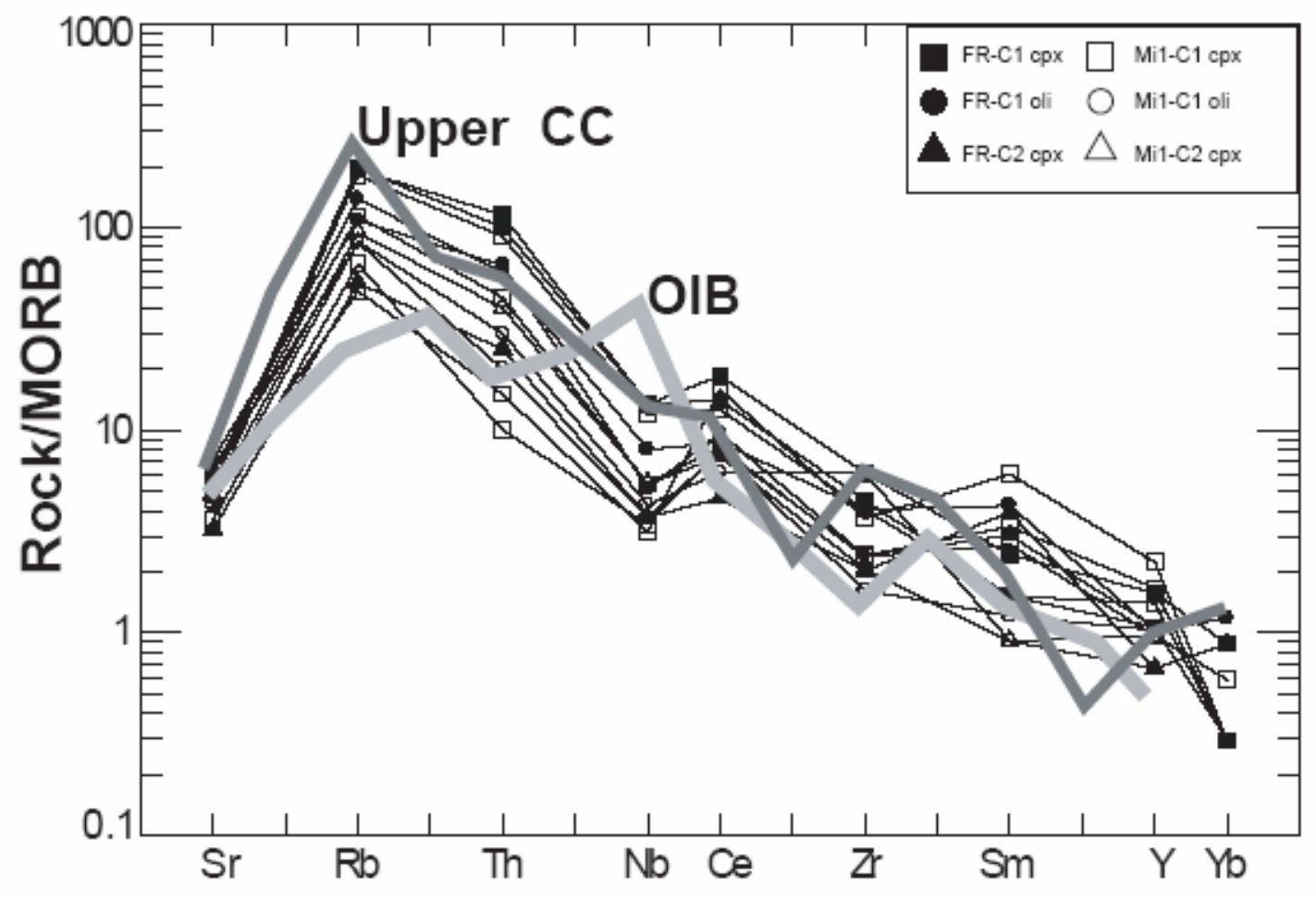

Fig.11 


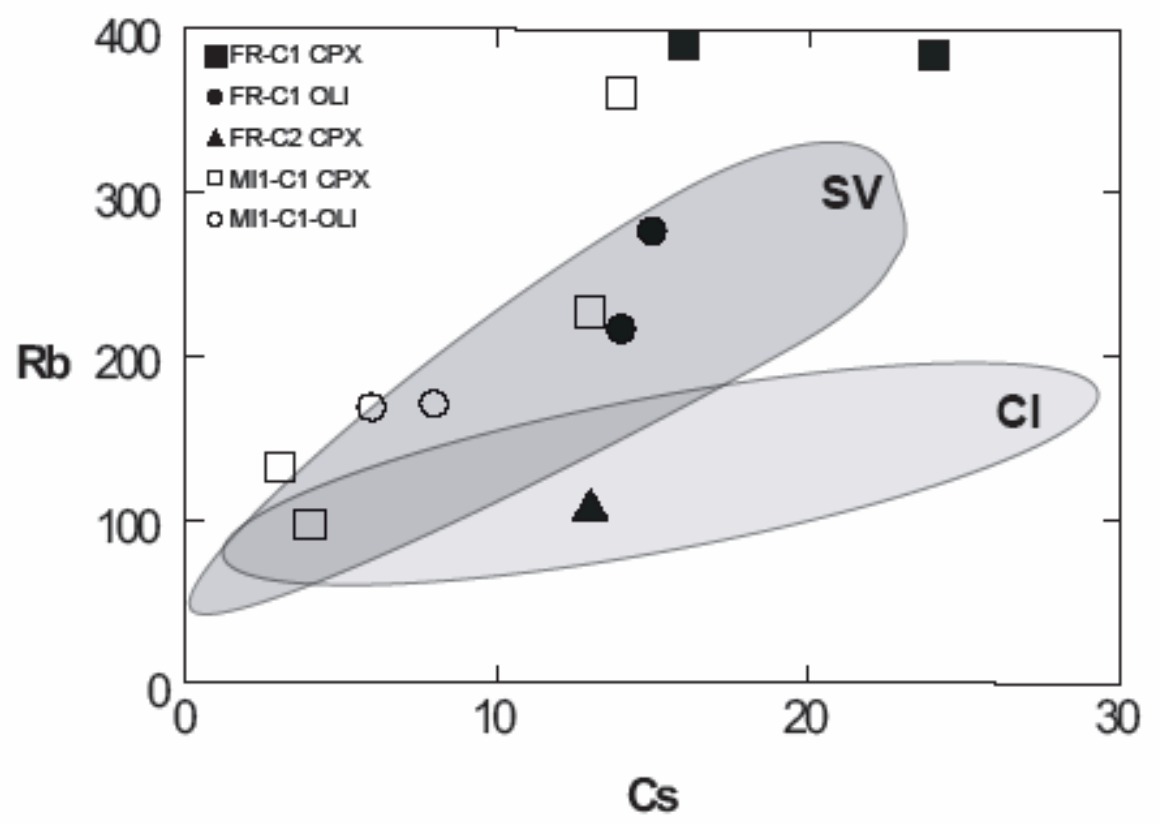

Fig.12 


\section{FIGURE CAPTIONS}

Figure 1. Schematic map of the Campi Flegrei area showing sample locations (modified after Pappalardo et al., 1999).

Figure 2. Change in appearance of two crystallized silicate melt inclusions hosted in clinopyroxene in Fondo Riccio scoria as a result of heating from room temperature $\left(22^{\circ} \mathrm{C}\right)$ to the homogenization temperature $\left(1137^{\circ} \mathrm{C}\right)$. After heating to $1137^{\circ} \mathrm{C}$ the inclusion contains only a vapor bubble. The $\mathrm{MI}$ is approximately $\mathrm{xx} \mu \mathrm{m}$ in diameter.

Figure 3. Classification diagrams for pyroxene and olivine phenocrysts (Morimoto, 1988). Filled squares $=$ compositions of MI hosted in clinopyroxene from FR-C1 (scoria); filled circles = composition of MI hosted in olivine from FR-C1 (scoria); filled triangles = compositions of $\mathrm{MI}$ hosted in clinopyroxene from FR-C2 (bomb); open squares = compositions of $\mathrm{MI}$ hosted in clinopyroxene from Mi1-C1; open circles = compositions of MI hosted in olivine from Mi1-C1; open triangles = composition of MI hosted in clinopyroxenes from Mi1-C2.

Figure 4. Total alkali-silica diagram (Le Bas et al., 1986) showing compositions of MI hosted in clinopyroxene and olivine from Fondo Riccio and Minopoli 1. Bulk rock compositions are also shown.

Figure 5. Harker variation diagrams for $\mathrm{MI}$ plotted versus $\mathrm{SiO}_{2}$ : (a). $\mathrm{Al}_{2} \mathrm{O}_{3}$; (b). $\mathrm{CaO}$; (c) $\mathrm{Na}_{2} \mathrm{O}$; (d). $\mathrm{P}_{2} \mathrm{O}_{5}$; (e) $\mathrm{TiO}_{2}$; (f) $\mathrm{FeO}^{\text {tot }}$. 
Figure 6. Water contents of MI obtained by EMPA and SIMS.

Figure 7. Volatile concentrations in MI from Fondo Riccio and Minopoli 1 plotted versus $\mathrm{SiO}_{2}$ concentration.

Figure 8. Relationship between B and Be for Fondo Riccio and Minopoli 1 MI. The diagonal line corresponds to $\mathrm{B} / \mathrm{Be}=4$ and divides arc volcanic magmas from ocean island volcanic magmas. Both samples fall along the boundary line, suggesting a mixed arc volcanic and ocean island origin. Two data points for samples Mi1-C1-p6 M2 and FR-C1-o4 M1 have not been plotted.

Figure 9. Relationship between $\mathrm{Rb}$ and $\mathrm{Y}+\mathrm{Nb}$ for Fondo Riccio and Minopoli $1 \mathrm{MI}$. MI compositions are near the boundary between the volcanic arc and “within plate” fields, suggesting a mixed magma source (see also Fig.1 in Piochi et al., 2005).

Figure 10. Relationship between $\mathrm{Y} / \mathrm{Nb}$ and $\mathrm{Zr} / \mathrm{Nb}$ for Fondo Riccio and Minopoli $1 \mathrm{MI}$. Compositions of MI from both samples suggest an upper crustal magma source.

Figure 11 Spider diagram for Fondo Riccio and Minopoli 1 MI (Pearce, 1983). The heavier lines show the upper continental crust (Upper CC) and the oceanic island basalt (OIB) trends.

Figure 12 Relationship between $\mathrm{Rb}$ and Cs for Fondo Riccio and Minopoli $1 \mathrm{MI}$. The data suggest that the feeding mechanism of these two eruptions is more similar to the Somma-Vesuvius (SV) magma source than the Campanian Ignimbrite source. 


\section{Table 1a}

\begin{tabular}{|c|c|c|c|c|c|c|c|c|c|c|c|c|c|c|c|}
\hline \multirow{4}{*}{\begin{tabular}{|l|} 
Sample \\
MI label \\
Size $(\mu \mathrm{m})$ \\
Host $\mathbf{x I}$ \\
\end{tabular}} & \multicolumn{15}{|c|}{ FR-C1 FR-C1 FR-C1 FR-C1 FR-C1 F } \\
\hline & \multicolumn{4}{|c|}{ p6 M1 p6 M2 p6 M4 p6 M5 } & \multicolumn{4}{|c|}{ p6 M6 p6 M7 p6 M8p6 M9 } & p11 M1 & \multicolumn{2}{|c|}{ p12 M1 p12 M2 } & $201 \mathrm{M1}$ & \multicolumn{2}{|c|}{ o2 M1 04 M1 } & \multirow{2}{*}{$\begin{array}{c}06 \mathrm{M1} \\
50\end{array}$} \\
\hline & 75 & 80 & 35 & 30 & 60 & 55 & 75 & 55 & 85 & 50 & 130 & 70 & 50 & 60 & \\
\hline & $\operatorname{cpx}$ & $\mathrm{cpx}$ & $\operatorname{cpx}$ & $\mathrm{cpx}$ & $\operatorname{cpx}$ & $\operatorname{cpx}$ & $\mathrm{cpx}$ & $\mathrm{cpx}$ & $\mathrm{cpx}$ & $\mathrm{cpx}$ & $\mathrm{cpx}$ & ol & ol & ol & ol \\
\hline $\mathrm{T}$ (quen) ${ }^{\circ} \mathrm{C}$ & 1128 & 1126 & 1128 & 1128 & 1128 & 1126 & 1126 & 1126 & 1145 & 1139 & 1139 & 1172 & 1150 & 1175 & 1135 \\
\hline Host Mg\# & 74.41 & 73.37 & 73.68 & 75.16 & 76.11 & 83.17 & 78.04 & 86.12 & 83.17 & 78.04 & 86.12 & 86.77 & 86.56 & 84.85 & 84.70 \\
\hline \multicolumn{16}{|c|}{ Host xl composition } \\
\hline $\mathrm{SiO}_{2}$ & 49.93 & 50.24 & 50.24 & 50.36 & 50.36 & 50.38 & 50.74 & 50.41 & 51.68 & 49.01 & 49.80 & 40.15 & 40.02 & 40.74 & 39.77 \\
\hline $\mathrm{TiO}_{2}$ & 0.62 & 0.63 & 0.63 & 0.63 & 0.63 & 0.63 & 0.59 & 0.53 & 0.32 & 0.77 & 0.67 & 0.05 & 0.00 & 0.04 & 0.00 \\
\hline $\mathrm{Al}_{2} \mathrm{O}_{3}$ & 3.21 & 3.35 & 3.35 & 3.02 & 3.02 & 3.02 & 3.27 & 3.17 & 3.02 & 4.13 & 3.63 & 0.01 & 0.01 & 0.03 & 0.02 \\
\hline $\mathrm{FeO}$ & 8.52 & 8.71 & 8.71 & 8.71 & 8.71 & 8.71 & 8.17 & 7.99 & 5.62 & 7.43 & 6.49 & 13.06 & 12.90 & 13.89 & 14.71 \\
\hline $\mathrm{MnO}$ & 0.44 & 0.48 & 0.48 & 0.40 & 0.40 & 0.40 & 0.39 & 0.39 & 0.11 & 0.24 & 0.21 & 0.23 & 0.25 & 0.28 & 0.30 \\
\hline $\mathrm{MgO}$ & 13.90 & 13.47 & 13.47 & 13.68 & 13.68 & 13.68 & 13.87 & 14.27 & 15.59 & 14.83 & 15.23 & 48.06 & 46.62 & 44.00 & 45.71 \\
\hline $\mathrm{CaO}$ & 22.45 & 22.41 & 22.41 & 22.25 & 22.25 & 22.25 & 22.04 & 21.92 & 22.78 & 21.91 & 22.37 & 0.36 & 0.32 & 0.30 & 0.31 \\
\hline $\mathrm{Na}_{2} \mathrm{O}$ & 0.36 & 0.41 & 0.41 & 0.37 & 0.37 & 0.37 & 0.34 & 0.37 & 0.17 & 0.28 & 0.22 & 0.03 & 0.01 & 0.01 & 0.01 \\
\hline $\mathrm{K}_{2} \mathrm{O}$ & 0.02 & 0.00 & 0.00 & 0.02 & 0.02 & 0.02 & 0.01 & 0.00 & 0.01 & 0.01 & 0.02 & 0.02 & 0.01 & 0.00 & 0.03 \\
\hline $\mathrm{P}_{2} \mathrm{O}_{6}$ & 0.02 & 0.02 & 0.02 & 0.02 & 0.02 & 0.02 & 0.03 & 0.00 & 0.01 & 0.01 & 0.01 & 0.02 & 0.01 & 0.00 & 0.02 \\
\hline Total & 99.57 & 99.99 & 99.89 & 99.67 & 99.67 & 99.67 & 99.50 & 99.09 & 99.36 & 98.71 & 98.70 & 102.14 & 98.82 & 99.38 & 100.90 \\
\hline Wo & 27.3 & 27.3 & 27.3 & 27.3 & 27.3 & 27.3 & 27.3 & 27.3 & 51.7 & 50.5 & 50.5 & 0.6 & 0.5 & 0.5 & 0.5 \\
\hline En & 56.5 & 56.5 & 56.5 & 56.5 & 56.5 & 56.5 & 56.5 & 56.5 & 35.4 & 34.4 & 34.4 & 77.9 & 77.6 & 75.3 & 74.9 \\
\hline Fs & 16.2 & 16.2 & 16.2 & 16.2 & 16.2 & 16.2 & 16.2 & 16.2 & 13.0 & 15.1 & 15.1 & 21.5 & 21.9 & 24.2 & 24.6 \\
\hline \multicolumn{16}{|c|}{ Melt inclusions composition } \\
\hline \multicolumn{16}{|c|}{ Electron Microprobe } \\
\hline $\mathrm{SiO}_{2}$ & 57.86 & 58.12 & 58.18 & 58.80 & 58.16 & 58.30 & 59.38 & 56.08 & 52.06 & 55.06 & 48.33 & 47.69 & 46.83 & 48.09 & 49.57 \\
\hline $\mathrm{TiO}_{2}$ & 0.53 & 0.54 & 0.48 & 0.51 & 0.53 & 0.46 & 0.47 & 0.61 & 0.72 & 0.68 & 0.98 & 0.87 & 0.89 & 0.94 & 0.87 \\
\hline $\mathrm{Al}_{2} \mathrm{O}_{3}$ & 16.32 & 16.81 & 17.55 & 16.35 & 17.33 & 16.58 & 18.32 & 17.44 & 18.88 & 18.19 & 14.39 & 13.88 & 12.77 & 14.31 & 16.52 \\
\hline $\mathrm{FeO}^{\text {tot }}$ & 4.01 & 3.58 & 2.77 & 3.54 & 2.97 & 3.61 & 1.98 & 5.21 & 4.68 & 3.51 & 5.94 & 7.21 & 8.22 & 7.71 & 6.86 \\
\hline $\mathrm{MnO}$ & 0.26 & 0.23 & 0.16 & 0.32 & 0.14 & 0.16 & 0.13 & 0.07 & 0.15 & 0.08 & 0.11 & 0.12 & 0.18 & 0.17 & 0.18 \\
\hline $\mathrm{MgO}$ & 1.91 & 1.74 & 1.44 & 1.64 & 1.47 & 1.66 & 1.21 & 2.05 & 3.08 & 2.25 & 6.11 & 8.05 & 9.45 & 6.92 & 4.91 \\
\hline $\mathrm{CaO}$ & 4.81 & 4.74 & 4.14 & 4.54 & 4.16 & 4.51 & 3.86 & 5.02 & 7.32 & 7.42 & 11.35 & 10.15 & 9.42 & 9.96 & 9.86 \\
\hline $\mathrm{Na}_{2} \mathrm{O}$ & 3.40 & 3.61 & 3.60 & 3.38 & 3.73 & 3.53 & 3.57 & 3.60 & 3.70 & 2.54 & 1.73 & 1.57 & 1.33 & 1.41 & 1.72 \\
\hline $\mathrm{K}_{2} \mathrm{O}$ & 7.85 & 7.78 & 8.18 & 7.69 & 8.25 & 7.94 & 8.57 & 7.12 & 5.42 & 6.92 & 4.64 & 4.67 & 4.41 & 4.58 & 5.21 \\
\hline $\mathrm{P}_{2} \mathrm{O}_{6}$ & 0.22 & 0.14 & 0.27 & 0.14 & 0.21 & 0.14 & 0.27 & 0.30 & 1.03 & 0.31 & 0.87 & 0.61 & 0.62 & 0.56 & 0.67 \\
\hline NiO & 0.00 & 0.00 & 0.00 & 0.00 & 0.00 & 0.00 & 0.00 & 0.00 & 0.00 & 0.00 & 0.00 & 0.00 & 0.00 & 0.00 & 0.00 \\
\hline $\mathrm{SO}_{2}$ & 0.07 & 0.08 & 0.04 & 0.13 & 0.08 & 0.07 & 0.09 & 0.04 & 0.16 & 0.05 & 0.29 & 0.33 & 0.40 & 0.31 & 0.25 \\
\hline$F$ & 0.21 & 0.12 & 0.14 & 0.17 & 0.17 & 0.22 & 0.28 & 0.17 & 0.31 & 0.00 & 0.08 & 0.27 & 0.14 & 0.15 & 0.18 \\
\hline $\mathrm{Cl}$ & 0.58 & 0.71 & 0.57 & 0.58 & 0.54 & 0.62 & 0.53 & 0.46 & 0.58 & 0.32 & 0.47 & 0.42 & 0.44 & 0.47 & 0.42 \\
\hline Total & 97.83 & 97.96 & 97.52 & 97.76 & 97.74 & 97.76 & 98.48 & 98.15 & 98.09 & 97.27 & 95.29 & 95.85 & 95.08 & 95.58 & 97.22 \\
\hline \multicolumn{16}{|c|}{ Ion Microprobe } \\
\hline $\mathrm{H}_{2} \mathrm{O}(w t \%)$ & - & 6.96 & - & - & - & - & 3.66 & - & - & - & - & 4.13 & - & 3.61 & - \\
\hline Li ppm & - & 28 & - & - & - & - & 28 & - & - & - & - & 15 & - & 11 & - \\
\hline $\mathrm{Be}$ & - & 13 & - & - & - & - & 16 & - & - & - & - & 9 & - & 52 & - \\
\hline B & - & 62 & - & - & - & - & 59 & - & - & - & - & 39 & - & 55 & - \\
\hline $\mathbf{R b}$ & - & 316 & - & - & - & - & 316 & - & - & - & - & 218 & - & 276 & - \\
\hline Sr & - & 627 & - & - & - & - & 614 & - & - & - & - & 1043 & - & 902 & - \\
\hline$Y$ & - & 53 & - & - & - & - & 35 & - & - & - & - & 45 & - & 43 & - \\
\hline $\mathrm{Zr}$ & - & 364 & - & - & - & - & 262 & - & - & - & - & 176 & - & 292 & - \\
\hline $\mathrm{Nb}$ & - & 49 & - & - & - & - & 48 & - & - & - & - & 23 & - & 35 & - \\
\hline Cs & - & 25 & - & - & - & - & 16 & - & - & - & - & 19 & - & 19 & - \\
\hline $\mathrm{Ce}$ & - & 172 & - & - & - & - & 128 & - & - & - & - & 112 & - & 98 & - \\
\hline Nd & - & 47 & - & - & - & - & 32 & - & - & - & - & 38 & - & 97 & - \\
\hline $\mathrm{Sm}$ & - & 1 & - & - & - & - & 1 & - & - & - & - & 2 & - & 3 & - \\
\hline Dy & - & 4 & - & - & - & - & $<1$ & - & - & - & - & 2 & - & 3 & - \\
\hline $\mathrm{Yb}$ & - & 1 & - & - & - & - & $<1$ & - & - & - & - & 2 & - & 2 & - \\
\hline Th & - & 29 & - & - & - & - & 25 & - & - & - & - & 21 & - & 19 & - \\
\hline U & - & 12 & - & - & $=$ & - & 7 & - & - & - & - & 5 & - & 9 & - \\
\hline
\end{tabular}




\section{Table 1b}

\begin{tabular}{|c|c|c|c|c|c|}
\hline Sample & FR-C2 & FR-C2 & FR-C2 & FR-C2 & FR-C2 \\
\hline MI label & p2 M1 & p4 M1 & p5 M1 & p6 M1 & p7 M1 \\
\hline Size $(\mu \mathrm{m})$ & 20 & 40 & 80 & 100 & 40 \\
\hline Host xl & $\mathrm{cpx}$ & $\mathrm{cpx}$ & $\mathrm{cpx}$ & $\mathrm{cpx}$ & $\mathrm{cpx}$ \\
\hline $\mathrm{T}$ (quen) ${ }^{\circ} \mathrm{C}$ & 1176 & 1135 & 1185 & 1152 & 1164 \\
\hline Host Mg\# & 88.68 & 86.94 & 88.57 & 84.98 & 84.62 \\
\hline \multicolumn{6}{|c|}{ Host $\mathrm{xl}$ composition } \\
\hline $\mathrm{SiO}_{2}$ & 53.70 & 52.03 & 52.11 & 51.25 & 51.67 \\
\hline $\mathrm{TiO}_{2}$ & 0.36 & 0.44 & 0.39 & 0.60 & 0.54 \\
\hline $\mathrm{Al}_{2} \mathrm{O}_{3}$ & 2.09 & 2.48 & 2.11 & 2.79 & 3.21 \\
\hline $\mathrm{FeO}$ & 3.76 & 4.38 & 3.93 & 5.06 & 5.00 \\
\hline MnO & 0.10 & 0.14 & 0.08 & 0.17 & 0.12 \\
\hline $\mathrm{MgO}$ & 16.53 & 16.36 & 17.09 & 16.07 & 15.44 \\
\hline $\mathrm{CaO}$ & 23.25 & 23.01 & 23.00 & 22.47 & 23.02 \\
\hline $\mathrm{Na}_{2} \mathrm{O}$ & 0.11 & 0.11 & 0.09 & 0.15 & 0.12 \\
\hline $\mathrm{K}_{2} \mathrm{O}$ & 0.00 & 0.01 & 0.02 & 0.01 & 0.00 \\
\hline $\mathrm{P}_{2} \mathrm{O}_{6}$ & 0.02 & 0.04 & 0.01 & 0.06 & 0.01 \\
\hline Total & 100.07 & 99.05 & 98.94 & 98.67 & 99.20 \\
\hline Wo & 53.3 & 52.4 & 52.2 & 51.3 & 52.8 \\
\hline En & 37.9 & 37.3 & 38.8 & 36.7 & 35.4 \\
\hline Fs & 8.8 & 10.3 & 9.1 & 11.9 & 117 \\
\hline \multicolumn{6}{|c|}{ Melt inclusions composition } \\
\hline \multicolumn{6}{|c|}{ Electron Microprobe } \\
\hline $\mathrm{SiO}_{2}$ & 49.09 & 49.08 & 48.87 & 47.72 & 53.01 \\
\hline $\mathrm{TiO}_{2}$ & 1.00 & 0.97 & 0.91 & 1.28 & 1.08 \\
\hline $\mathrm{Al}_{2} \mathrm{O}_{3}$ & 12.84 & 13.88 & 12.76 & 12.81 & 20.34 \\
\hline $\mathrm{FeO}^{6 \mathrm{t}}$ & 7.00 & 5.94 & 6.57 & 7.92 & 3.44 \\
\hline $\mathrm{MnO}$ & 0.10 & 0.15 & 0.15 & 0.28 & 0.16 \\
\hline $\mathrm{MgO}$ & 6.81 & 6.17 & 7.33 & 6.90 & 2.12 \\
\hline $\mathrm{CaO}$ & 10.65 & 11.27 & 11.88 & 12.40 & 6.06 \\
\hline $\mathrm{Na}_{2} \mathrm{O}$ & 1.31 & 1.42 & 1.46 & 1.36 & 2.83 \\
\hline $\mathrm{K}_{2} \mathrm{O}$ & 4.07 & 4.20 & 4.23 & 2.60 & 7.83 \\
\hline $\mathrm{P}_{2} \mathrm{O}_{6}$ & 0.60 & 0.36 & 0.44 & 0.46 & 1.36 \\
\hline NiO & 0.00 & 0.00 & 0.00 & 0.00 & 0.00 \\
\hline $\mathrm{SO}_{2}$ & 0.34 & 0.27 & 0.19 & 0.26 & 0.13 \\
\hline F & 0.07 & 0.40 & 0.18 & 0.10 & 0.08 \\
\hline $\mathrm{Cl}$ & 0.44 & 0.40 & 0.43 & 0.33 & 0.39 \\
\hline Total & 94.31 & 94.49 & 95.40 & 94.42 & 98.81 \\
\hline \multicolumn{6}{|c|}{ Ion Microprobe } \\
\hline $\mathrm{H}_{2} \mathrm{O}$ & 3.25 & - & - & - & - \\
\hline Li & 11 & - & - & - & - \\
\hline $\mathrm{Be}$ & 3 & - & - & - & - \\
\hline$B$ & 24 & - & - & - & - \\
\hline $\mathbf{R b}$ & 98 & - & - & - & - \\
\hline Sr & 431 & - & - & - & - \\
\hline$Y$ & 25 & - & - & - & - \\
\hline $\mathrm{Zr}$ & 136 & - & - & - & - \\
\hline Nb & 16 & - & - & - & - \\
\hline Cs & 15 & - & - & - & - \\
\hline $\mathrm{Ce}$ & 48 & - & - & - & - \\
\hline Nd & 16 & - & - & - & - \\
\hline $\mathrm{Sm}$ & 3 & - & - & - & - \\
\hline Dy & 1 & - & - & - & - \\
\hline$Y b$ & 1 & - & - & - & - \\
\hline Th & 7 & - & - & - & - \\
\hline U & 6 & - & - & - & - \\
\hline
\end{tabular}


Table 1c

\begin{tabular}{|c|c|c|c|c|c|c|c|c|c|}
\hline Sample & Mi 1-C1 & Mi 1-C1 & Mi 1-C1 & Mi 1-C1 & Mi 1-C1 & Mi 1-C1 & Mi 1-C1 & Mi 1-C2 & Mi 1-C2 \\
\hline MI label & p2 M1 & p3 M1 & p6 M1 & p6 M2 & p8 M1 & o5 M1 & o6 M1 & p1 M1 & p1 M2 \\
\hline Size $(\mu \mathrm{m})$ & 50 & 60 & 50 & 70 & 40 & 60 & 55 & 45 & 50 \\
\hline Host xl & $\mathrm{cpx}$ & $\mathrm{cpx}$ & $\operatorname{cox}$ & $\mathrm{cpx}$ & $\mathrm{cpx}$ & olivine & olivine & $\mathrm{cpx}$ & $\cos x$ \\
\hline $\mathrm{T}$ (quen) ${ }^{\circ} \mathrm{C}$ & 1122 & 1149 & 1158 & 1156 & 1108 & 1120 & 1145 & 1122 & 1122 \\
\hline Host Mg\# & 86.64 & 88.59 & 85.10 & 86.10 & 86.29 & 86.68 & 85.68 & 89.89 & 89.89 \\
\hline \multicolumn{10}{|c|}{ Host $\mathbf{x l}$ composition } \\
\hline $\mathrm{SiO}_{2}$ & 52.39 & 52.96 & 52.52 & 52.52 & 52.78 & 39.38 & 38.98 & 52.67 & 52.67 \\
\hline $\mathrm{TiO}_{2}$ & 0.41 & 0.33 & 0.43 & 0.43 & 0.36 & 0.00 & 0.01 & 0.25 & 0.25 \\
\hline $\mathrm{Al}_{2} \mathrm{O}_{3}$ & 3.03 & 2.19 & 3.35 & 3.35 & 2.78 & 0.02 & 0.02 & 1.68 & 1.68 \\
\hline $\mathrm{FeO}$ & 4.36 & 3.72 & 4.97 & 4.97 & 4.58 & 12.66 & 13.70 & 3.37 & 3.37 \\
\hline MnO & 0.14 & 0.10 & 0.10 & 0.10 & 0.11 & 0.20 & 0.22 & 0.09 & 0.09 \\
\hline MgO & 15.86 & 16.20 & 15.92 & 15.92 & 16.18 & 46.22 & 45.99 & 16.82 & 16.82 \\
\hline $\mathrm{CaO}$ & 22.75 & 23.39 & 21.52 & 21.52 & 22.53 & 0.28 & 0.27 & 23.53 & 23.53 \\
\hline $\mathrm{Na}_{2} \mathrm{O}$ & 0.14 & 0.13 & 0.15 & 0.15 & 0.13 & 0.02 & 0.04 & 0.15 & 0.15 \\
\hline $\mathrm{K}_{2} \mathrm{O}$ & 0.01 & 0.03 & 0.02 & 0.02 & 0.01 & 0.03 & 0.01 & 0.01 & 0.01 \\
\hline $\mathrm{P}_{2} \mathrm{O}_{6}$ & 0.02 & 0.04 & 0.00 & 0.00 & 0.00 & 0.00 & 0.02 & 0.00 & 0.00 \\
\hline Total & 99.11 & 99.07 & 98.99 & 98.99 & 99.45 & 98.82 & 99.22 & 98.56 & 98.56 \\
\hline Wo & 52.8 & 53.9 & 50.6 & 50.6 & 51.9 & 0.5 & 0.4 & 53.7 & 53.7 \\
\hline En & 36.8 & 37.3 & 37.5 & 37.5 & 37.3 & 77.9 & 76.4 & 38.4 & 38.4 \\
\hline Fs & 10.4 & 8.8 & 11.9 & 11.9 & 10.8 & 21.7 & 23.1 & 7.8 & 7.9 \\
\hline \multicolumn{10}{|c|}{ Melt inclusions composition } \\
\hline \multicolumn{10}{|c|}{ Electron Microprobe } \\
\hline $\mathrm{SiO}_{2}$ & 46.94 & 48.20 & 51.79 & 49.96 & 50.19 & 47.81 & 47.98 & 51.11 & 50.75 \\
\hline $\mathrm{TiO}_{2}$ & 1.05 & 0.76 & 0.68 & 0.76 & 0.79 & 0.66 & 0.78 & 0.72 & 0.90 \\
\hline $\mathrm{Al}_{2} \mathrm{O}_{3}$ & 13.97 & 11.98 & 10.70 & 10.15 & 16.54 & 13.81 & 14.61 & 13.18 & 13.47 \\
\hline $\mathrm{FeO}^{\text {tot }}$ & 9.58 & 8.20 & 7.50 & 7.68 & 5.99 & 6.80 & 7.73 & 6.84 & 7.11 \\
\hline $\mathrm{MnO}$ & 0.29 & 0.10 & 0.21 & 0.15 & 0.17 & 0.12 & 0.08 & 0.10 & 0.17 \\
\hline MgO & 5.65 & 8.00 & 7.98 & 8.93 & 5.40 & 11.53 & 9.37 & 6.92 & 6.93 \\
\hline $\mathrm{CaO}$ & 10.80 & 12.75 & 12.23 & 13.35 & 9.20 & 7.57 & 8.94 & 10.34 & 11.01 \\
\hline $\mathrm{Na}_{2} \mathrm{O}$ & 1.82 & 1.30 & 1.16 & 1.03 & 1.71 & 1.50 & 1.57 & 1.24 & 1.30 \\
\hline $\mathrm{K}_{2} \mathrm{O}$ & 3.24 & 3.17 & 2.91 & 2.58 & 4.76 & 4.11 & 3.92 & 3.88 & 4.07 \\
\hline $\mathrm{P}_{2} \mathrm{O}_{6}$ & 0.38 & 0.38 & 0.26 & 0.24 & 0.70 & 0.98 & 0.56 & 0.84 & 0.62 \\
\hline $\mathrm{NiO}$ & 0.14 & 0.05 & 0.04 & 0.00 & 0.02 & 0.08 & 0.05 & 0.00 & 0.00 \\
\hline $\mathrm{SO}_{2}$ & 0.11 & 0.91 & 0.09 & 0.10 & 0.10 & 0.34 & 0.21 & 0.31 & 0.37 \\
\hline $\mathrm{F}$ & 0.29 & 0.03 & 0.01 & 0.03 & 0.09 & 0.07 & 0.17 & 0.00 & 0.00 \\
\hline $\mathrm{Cl}$ & 0.30 & 0.28 & 0.20 & 0.20 & 0.34 & 0.43 & 0.43 & 0.42 & 0.39 \\
\hline Total & 94.56 & 96.11 & 95.74 & 95.14 & 96.00 & 95.81 & 96.38 & 95.68 & 97.06 \\
\hline \multicolumn{10}{|c|}{ Ion Microprobe } \\
\hline $\mathrm{H}_{2} \mathrm{O}$ & 5.15 & - & 1.93 & 1.29 & 5.28 & 3.89 & 4.40 & 5.15 & - \\
\hline $\mathrm{Li}$ & 21 & - & 11 & 12 & 24 & 7 & 18 & 21 & - \\
\hline $\mathrm{Be}$ & 14 & - & 7 & 77 & 7 & 12 & 1 & 14 & - \\
\hline B & 31 & - & 27 & 320 & 44 & 36 & 32 & 47 & - \\
\hline $\mathrm{Rb}$ & 97 & - & 324 & 122 & 215 & 168 & 167 & 176 & - \\
\hline Sr & 687 & - & 814 & 480 & 785 & 607 & 889 & 646 & - \\
\hline $\mathrm{Y}$ & 92 & - & 52 & 63 & 37 & 27 & 42 & 37 & - \\
\hline $\mathrm{Zr}$ & 268 & - & 262 & 160 & 182 & 437 & 116 & 139 & - \\
\hline $\mathrm{Nb}$ & 14 & - & 48 & 14 & 23 & 19 & 16 & 22 & - \\
\hline Cs & 8 & - & 16 & 4 & 16 & 10 & 8 & 93 & - \\
\hline Ce & 180 & - & 128 & 83 & 88 & 69 & 87 & 79 & - \\
\hline Nd & 180 & - & 32 & 74 & 63 & 61 & 75 & 53 & - \\
\hline Sm & 4 & - & 1 & 2 & 2 & 1 & 1 & 1 & - \\
\hline Dy & 2 & - & $<1$ & 1 & 1 & $<1$ & $<1$ & $<1$ & - \\
\hline $\mathrm{Yb}$ & $<1$ & - & 1 & $<1$ & 1 & $<1$ & $<1$ & $<1$ & - \\
\hline Th & 5 & - & 25 & 3 & 14 & 9 & 6 & 13 & - \\
\hline U & 1 & - & 7 & 2 & 4 & 3 & $<1$ & $<1$ & - \\
\hline
\end{tabular}




\section{Table 2}

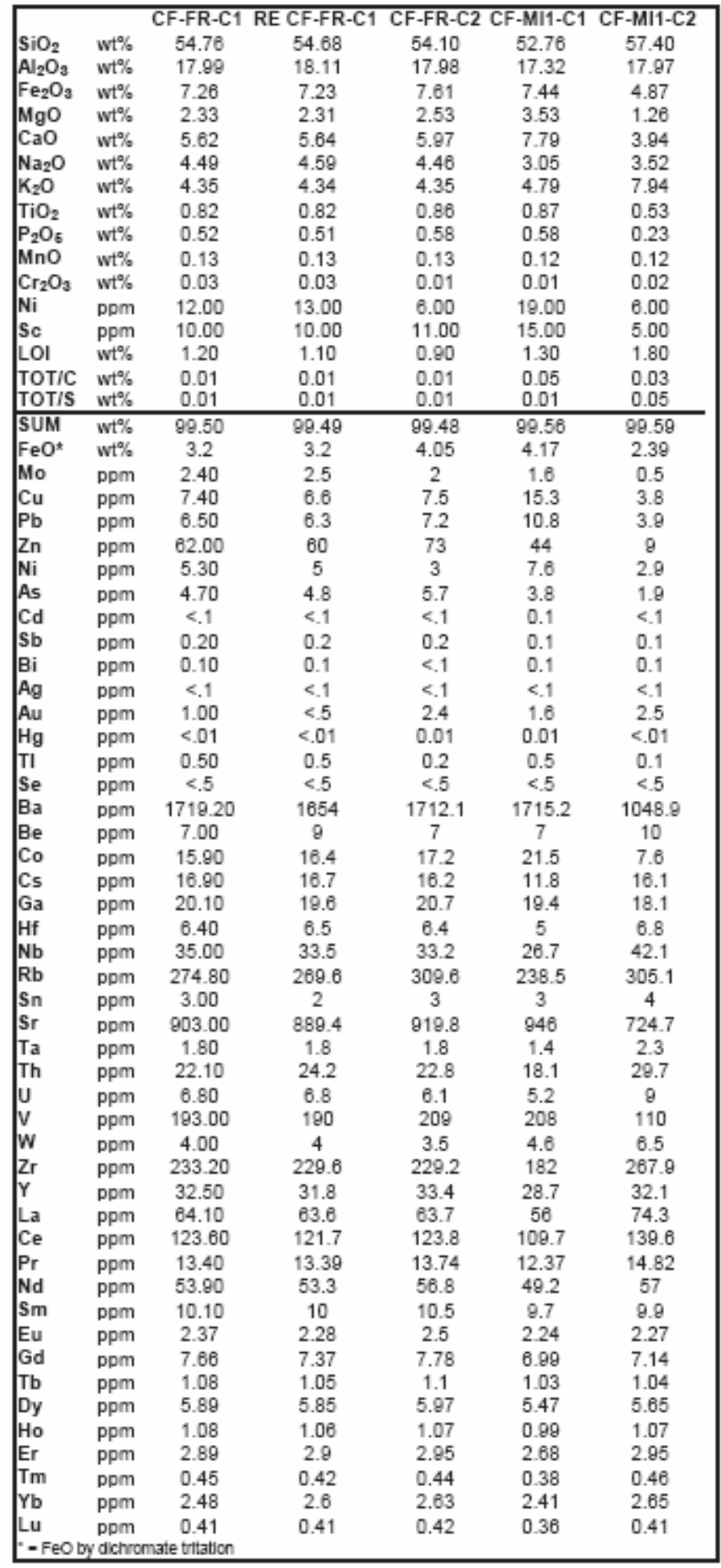




\section{TABLE CAPTIONS}

Table 1 MI composition determined by EMPA and SIMS. *T(run) = maximum temperature of heating experiment. Cpx = clinopyroxene host crystal. $\mathrm{Ol}=$

olivine host crystal: (a). Fondo Riccio C1; (b). Fondo Riccio C2; (c). Minopoli 1 (C1-C2).

Table 2 Fondo Riccio and Minopoli 1 bulk rock compositions determined by XRF. 


\section{REFERENCES}

Anderson A.T., 1974. Chlorine, sulfur and water in magmas and oceans. Geol. Soc. Am. Bull., 85, 1485-1492

Anderson A.T., 1976. Magma mixing: Petrological process and volcanological tool. J. Volcanol. Geotherm. Res., 1, 3-33.

Anderson A.T., 2003. An introduction to melt (glass \pm crystals) inclusions. In "Fluid Inclusions. Analysis and Interpretations". Min. Assoc. Canada, vol 32, pp374

Barberi F., Cassano E., La Torre P. and Sbrana A., 1991. Structural evolution of Campi Flegrei Caldera in light of volcanological and geophysical data. J. Volcanol. Geotherm. Res., 48 (1/2), 33-49

Burnham C.W., 1979. The importance of volatile constituents. In "The evolution of the igneous rocks; $50^{\text {th }}$ anniversary perspective". Princeton University Press, 439-482.

Carroll M. R., Holloway J.R., 1994 Volatiles in magma. Mineral. Soc. Am. Rev. Mineral., 30

Clocchiatti R., 1975. Les inclusions vitreuses des cristaux de quartz, Etude optique, thermooptique et chemique, Applications geologiques. Soc.Geol.France, Memoires, New Series, 122, 96 pp.

Cundari A., Fergusson A.K., 1982. Significance of the pyroxene chemistry from leucitebearing rocks and related assemblages. Tschermaks. Mineral. Petrogr. Mitt., 30, $189-204$

Danyushevsky L.V., Della Pasqua F.N., Sokolov S., 2000. Re-equilibration of melt inclusions trapped by magnesian olivine phenocrysts from subduction-related magmas: petrological implications. Contrib. Mineral. Petrol., 138, 68-83 
D’Antonio M., Civetta L., Di Girolamo P., 1999. Mantle source heterogeneity in the Campanian Region (South Italy) as inferred from geochemical and isotopic features of mafic volcanic rocks with shoshonitic affinity. Mineral Petrol, 67, 163-192

D’Argenio, B., T. Pescatore, and P. Scandone (1973), Schema geologico dell'Appennino Meridionale (Campania e Lucania), in Moderne Vedute della Geologia dell'Appennino, p. 183, Accad. Nazl. dei Lincei, Roma, Italy.

Deino A. L., Orsi G., de Vita S., Piochi M. 2004 The age of the Neapolitan Yellow Tuff caldera-forming eruption (Campi Flegrei caldera-Italy) assessed by ${ }^{40} \mathrm{Ar} /{ }^{39} \mathrm{Ar}$ dating method. J. Volcanol. Geotherm. Res., 133, 157-170

De Vivo B., Rolandi G., Gans P.B., Calvert A., Bohrson W.A., Spera F.J. and Belkin H.E., 2001. New constraints on the pyroclastic eruptive history of the Campanian volcanic Plain (Italy). Mineralogy and Petrology, 73, 121-143.

De Vivo B., Lima A. and Webster J. D., 2005. Volatiles in magmatic-volcanic systems. Elements, 1, 19-24.

De Vivo B. and Lima A. (in press). A hydrothermal model for ground movements (bradyseism) at Campi Flegrei, Italy. In: De Vivo B. (Edt), "Volcanisn in the Campania Plain: Vesuvius, Campi Flegrei and Ignimbrites". Developments in Volcanology 9, Elsevier.

Di Girolamo P., Ghiara M.R., Lirer L., Munno R., Rolandi G., Stanzione D., 1984. Vulcanologia e Petrologia dei Campi Flegrei. Boll Soc Geol It, 103, 349-413Di Vito M.A., Lirer L., Mastrolorenzo G., Rolandi G., 1987 The 1538 Monte Nuovo eruption (Campi Flegrei, Italy). Bull Volc, 49, no.4, 608-615 
Di Vito M.A., Isaia R., Orsi G., Southon J., D’Antonio M, de Vita S., Pappalardo L., Piochi M., 1999. Volcanic and deformation history of the Campi Flegrei caldera in the past $12 \mathrm{ka}$. J Volcanol Geotherm Res, 91, 221-246

Doglioni, C. (1991), A proposal for kinematic modeling of W dipping subductions. Possible applications to the Tyrrhenian-Apennines system, Terra Nova, 3, 426-434.

Fedele L., Bodnar R.J., DeVivo B. and Tracy R.J., 2003. Melt inclusion geochemistry and computer modeling of trachyte petrogenesis at Ponza, Italy. Chemical Geology, 194, 81-104.

Frezzotti M.L., 2001. Silicate-melt inclusions in magmatic rocks: application to petrology. Lithos 55, 273-299.

Gvirtzman Z. and Nur A. (2001). Residual topography, lithospheric structure and sunken slabs in the central Mediterranean. Earth Planet. Sci. LetT. 187, pp 117-130

Hippolyte J.C., Angelier J., and Roure F. (1994). A major geodynamic change revealed by Quaternary stress patterns in the Southern Apennines. Tectonophysics, 230, $199-210$.

Ippolito, F., D'Argenio B., Pescatore T., and Scandone P. (1975). Structural-stratigraphic units and tectonic framework of Southern Appennines. In Geology of Italy, edited by C. Squyres, pp. 317-328, Lybian Soc. of Earth Sci. Press, Libyan Arab Republic, Tripoli.

Le Bas M.J., Le Maitre R.W., Streckeisen A., Zanettin B., 1986. A chemical classification of volcanic rocks based on the total alkali-silica diagram. J Petrol, 27, $745-750$ 
Lima A., 2000. Experimental study in silicate melt inclusions in clinopyroxene phenocrysts from Roccamorfina lavas (Italy) Mineral and Petrol, 70, 199-220

Lima A., De Vivo B., Fedele L. and Sintoni M.F. (in press). Geochemical variations between the 79 AD and 1944 AD Mt. Somma-Vesuvius volcanic products: constraints on the evolution of the hydrothermal system based on fluid and melt inclusions. Chem. Geol. (this volume).

Lowenstern J.B., 1994. Dissolved volatile concentrations in ore-forming magma. Geology, 22, 893-896.

Marianelli P., Metrich N., Sbrana A. 1999. Shallow and deep reservoir involved in magma supply of the 1944 eruption of Vesuvius. Bull. Volc., 61, 48-63.

Meletti C., Patacca E., and Scandone P. (2000). Construction of a seismotectonic model: The case of Italy, Pure Appl. Geophys., 157, 11-35.

Morimoto N. 1988. Nomenclature of pyroxenes. Mineral. Mag., 52, p 535-550.

Orsi G., de Vita S. and Di Vito M., 1996. The restless, resurgent Campi Flegrei nested caldera (Italy): constraints on its evolution and configuration. J. Volcanol. Geotherm. Res., 74, 179-214.

Pappalardo L., Civetta L., D’Antonio M., Deino A.L., Di Vito M.A., Orsi G., Carandente A., de Vita S., Isaia R., Piochi M., 1999. Chemical and isotopical evolution of the Phlegraean magmatic system before the Campanian Ignimbrite $(37 \mathrm{ka})$ and the Neapolitan Yellow Tuff (12 ka) eruptions. J Volcanol Geotherm Res, 91, 141-166

Pappalardo L., Piochi M., D’Antonio M., Civetta L., Petrini R., 2002. Evidence for multistage magmatic evolution during the past $60 \mathrm{ka}$ at Campi Flegrei (Italy) deduced from $\mathrm{Sr}, \mathrm{Nd}$ and $\mathrm{Pb}$ isotope data. J. Petrol., 43, 1415-1434 
Pearce J.A., Harris B.W., Tindle A.G. (1984) Trace element discrimination diagrams for the tectonic interpretation of granitic rocks. J. Petrol., 25, 956-983

Peccerillo A. (1999). Multiple mantle metasomatism in central-southern Italy: Geochemical effects, timing and geodynamic implications, Geology, 27, 315-318.

Piochi M., Bruno P.P., De Astis G. (2005) Relative roles of rifting tectonics and magma ascent processes: Inferences from geophysical, structural, volcanological, and geochemical data for the Neapolitan volcanic region (southern Italy). Geochemistry, Geophysics, Geosystems, 6, n.7

Piromallo, C., and Morelli A. (1997). Imaging the Mediterranean upper mantle by Pwave travel time tomography, Ann. Geophys., 40, 963-979.

Roedder E., 1979. “Origin and significance of magmatic inclusions”, Bull. Mineral., 102 pp. $487-510$

Roedder E., 1984. "Fluid inclusions", Reviews Mineral.12, Mineral. Soc. Am., Washington D.C., 644 pp.

Rolandi G., Bellucci F., Heizler M.T., Belkin H.E. and De Vivo B., 2003. Tectonic controls on the genesis of ignimbrites from the Campanian Volcanic Zone, southern Italy. Mineralogy and Petrology, 79, 3 - 31.

Rosi M. and Sbrana A., 1987. Phlegrean Fields. CNR, Quaderni de "La Ricerca Scientifica", 114, 1-175.

Scandone P. (1979). Origin of the Tyrrhenian Sea and Calabrian Arc. Boll. Soc. Geol. Ital., 98, 27-34.

Selvaggi G., and Amato A. (1992). Subcrustal earthquakes in the Northern Apennines (Italy): Evidence for a still active subduction?. Geophys. Res. Lett., 19, 2127-2130. 
Selvaggi, G., and Chiarabba G. (1995). Seismicity and P-wave velocity image of the southern Tyrrhenian subduction zone. Geophys. J. Int., 121, 818-826.

Serri, G., Innocenti F., and Manetti P. (1993). Geochemical and petrological evidence of the subduction of delaminated Adriatic continental lithosphere in the genesis of the Neogene- Quaternary magmatism of central Italy. Tectonophysics, 223, 117-147.

Shimizu N., Hart S.R., 1982. Application of the ion probe to geochemistry and cosmochemistry. Ann. Rev. Earth Planet. Sci., 10, 483-526

Sobolev A.V., Kamenetsky V.S., Metrich N., Clocchiatti R., Koronova N.N., Devirts A.L., Ustinov V.I., 1990. Volatile regime and crystallization conditions in Etna hawaiite lavas. Geochem. Internat., 1990, 53-65

Sobolev A.V., 1996. Melt inclusions in minerals as a source of principle petrological information. Petrology, 4, 209-220

Sobolev A.V., Slutskii A.B., 1984. Composition and crystallization conditions of the initial melt of the Siberian meimechites in relation to the general problem of ultrabasic magmas. Sov. Geol. And Geophys., 25, 93-104

Student J. J., Bodnar R. J, 2004. Silicate melt inclusions in porphyry copper deposits: Identification and homogenization behavior. Canadian Mineralogist, 42, 1563-1600.

Thomas J.B., Bodnar R.J., 2002. A technique for mounting and polishing melt inclusions in small (>1 mm) crystals. Am. Min., vol.87, n.10, 1505-1508

Thomas J.B., Bodnar R.J., Shimizu N., Sinha A.K., 2002. Determination of zircon/melt trace element partition coefficients from SIMS analysis of melt inclusions in zircon. Geochimica et Cosmochimica Acta, 66, 2887-2902. 
Tonarini S., Leeman W.P., Civetta L., D’Antonio M., Ferrara G., Necco A. 2004 B/Nb and $\delta^{11} \mathrm{~B}$ systematics in the Phlegraean volcanic district, Italy. J Volcanol Geotherm Res, 133, 123-139.

Veksler, I. V., 2004. Liquid immiscibility and its role at magmatic-hydrothermal transition: a summary of experimental studies. Geoch. Geol., 210, 7-31

Wallace P.J., 2005 Volatiles in subduction zone magmas; concentrations and fluxes based on melt inclusion and volcanic gas data. J.Volcanol.Geotherm.Res. 140, 1-3, 217 240

Webster J. D., Burt D.M., Aguillon R. A., 1996. Volatile and lithophile trace-element geochemistry of heterogeneous Mexican tin rhyolite magmas deduced from compositions of melt inclusions. Geochim. Cosmochim. Acta, 60, 3267-3283

Webster J. D., Raia F., De Vivo B., Rolandi G., 2001. The behavior of chlorine and sulfur during differentiation of the Mt. Somma -Vesuvius magmatic system. Mineral. Petrol., 73, 177-201.

Webster J.D., Raia F., Tappen C., De Vivo B. (2003). Pre eruptive geochemistry of the ignimbrite-forming magmas of the Campanian Volcanic Zone, Southern Italy, determined from silicate melt inclusions. Mineral. Petrol., 79, 99-125 


\section{VITA}

Claudia Cannatelli was born in Rome, Italy in 1975. She graduated from "A. Labriola” Scientific Lyceum of Rome, Italy in 1994. She taught Informatics (1999-2000) and Physics (2000-2001) at ITT “M. Faraday" of Rome. She was a member of the Committee for the "Fanelli Prize- Mathematical Marathon" in Rome, Italy during the period 19982000. She attended the degree program at the Department of Physics "E. Amaldi", University of Rome "RomaTre" and she received a degree in Physics in 2003. She received her Master of Science degree in Geosciences at Virginia Tech in May 2006. She is currently a Ph.D. student at the University of Naples "Federico II" attending the Ph.D. program "Internal Dynamic of Magmatic System of Active Volcanoes" supported by MIUR (Italian Ministry of University and Research) and she anticipates finishing her Ph.D. program in December 2006. 